\title{
Makarnalık Buğdayda Kalite Islahı Çalışmaları
}

\author{
*Aliye PEHLIVAN ${ }^{1}$ Saime ÜNVER İKINCIKARAKAYA² \\ ${ }^{1}$ Tarla Bitkileri Merkez Araştırma Enstitüsü Müdürlüğü, Ankara \\ ${ }^{2}$ Ankara Üniversitesi, Ziraat Fakültesi, Tarla Bitkileri Bölümü, Ankara \\ *Sorumlu yazar e-posta (Corresponding author e-mail): aliye.pehlivan@tarim.gov.tr \\ Geliş Tarihi (Received): 02.05.2017 Kabul Tarihi (Accepted): 06.06.2017
}

\section{Öz}

Dünya ve ülkemiz tarımında çok önemli bir yere sahip olan makarnalık buğday (Triticum durum Desf.), makarna ve bulgur sanayisinin hammaddesini oluşturmaktadır. Ülkemiz endüstriyel üretiminde önemli bir yeri olan bu ürünler ihracatımızda da önemli bir paya sahiptir. Dış pazarda etkili olabilmek için, kaliteli üretim yaparak rekabet gücümüzü artırmamız ve hammadde olarak kaliteli makarnalık buğday üretimi gerekmektedir. Kaliteli makarnalık buğday üretimi için yetiştirme tekniklerinin iyileştirilmesi ve verimin artırılmasına paralel olarak farklı ekolojilerde kararlı (stabil) kalite özelliklerine sahip yeni çeşitlerin ıslahına intiyaç duyulmaktadır. Ülkemizde özel sektör tohumluk üretici kuruluşları, Ziraat Fakülteleri ve Tarımsal Araştırmalar ve Politikalar Genel Müdürlüğüne bağı araştırma enstitüleri verim ve kalitesi yüksek yeni makarnalık buğday çeşitlerin geliştirilmesi için ıslah çalışmaları yapmaktadırlar. Islah çalışmalarında makarna sanayinin istediği kalite özelliklerine (protein miktar ve kalitesi ve irmik rengi yüksek) sahip çeşitlerinin geliştirilmesi için ıslah materyalinin kalite yönüyle değerlendirilmesi çok önemlidir. Bu derlemede ülkemizdeki makarnalık buğday üretimi, çeşitleri, ve makarnalık buğday ıslah çalışmalarında, ıslah kademelerine göre kalitenin değerlendirilmesi hakkında bilgiler verilmeye çalışılmıştır.

Anahtar Kelimeler: Türkiye, makarnalık buğday, çeşit geliştirme, kalite ıslahı

\section{Quality Breeding Studies in Durum Wheat}

\section{Abstract}

Durum wheat (Triticum durum Desf.), has an important role in agriculture of Türkiye and world and it is the raw material of pasta and bulgur products. These products have an important role in both Turkey's industry and export. To be competitive on the world market, high quality durum wheat is needed as a raw material and end product should be in high quality. In order to produce high quality durum wheat, not only cultivation practices and grain yield should be improved but also there is need to breed new varieties which have both high and stable quality in different ecologies. In Türkiye durum wheat breeding studies are conducted by private breeding companies, agricultural faculties and research institutes belong to the General Directorate of Agricultural Research and Policies to develop new cultivars with high yield and quality. It is very important to evaluate breeding material in terms of quality parameters (high in protein quantity/quality and semolina colour) which expected by macaroni industry. In this review, it is aimed to give information about quality evaluation in different stages of durum wheat breeding and durum wheat cultivars in Türkiye.

Keywords: Türkiye, durum wheat, cultivar development, quality breeding

\section{Giriş}

$\mathrm{T}$ ürkiye genelinde gıda tüketimine bakıldığında, tahıl ve tahıl ürünlerinin tüketimi ilk sırada yer almaktadır. Tahılların başında gelen buğday genellikle ekmek, makarna, bulgur, irmik, erişte, kuskus ve diğer unlu mamuller şeklinde tüketilmektedir. Makarnalık buğday ise ülkemizde çoğunlukla makarna ve bulgur üretiminde az miktarlarda da olsa ekmek, irmik (makarna üretimi hariç), baklava ve kadayıf yapımında un paçallarında kullanılmaktadır. Makarna ve bulgur sanayi ülkemizde iç tüketimi karşılanmakta olup ihracatta önemli bir gelir sağlamaktadır. Türkiye Dünyanın en büyük makarnalık buğday üreticisi 
ülkelerinden biridir. Makarnalık buğdayın gen merkezlerinden biri olan Türkiye, ekolojik açıdan kaliteli makarnalık buğday yetiştirilmesine oldukça uygun bir ülkedir (Bozkurt 2012).

Son yıllarda Dünyada buğdayın makarna şeklinde tüketimi, ekmek şeklinde tüketimine oranla artmaktadır. Makarnanın uzun süre muhafaza edilebilmesi, çeşitliliği, kolayca hazırlanması, lezzeti, besleyici ve ekonomik bir gıda maddesi olması tüketiminin artmasını etkilemektedir. (Anonim 2010).

Türk Gıda Kodeksi Makarna Tebliği'ne göre makarnanın mutlaka durum buğdayından irmik ve su karışımından yapılması gerekmektedir. Makarna sanayinin temel hammaddesi makarnalık buğdaydan elde edilen irmiktir (Anonim 2002). Fakat Afrika ülkelerine yapılan makarna ihracatında rekabeti artırmak amacıyla ihraç edilecek makarnalarda istenirse \%30'a kadar ekmeklik buğday unwu kullanılabilmesine izin verilmiştir (Anonim 2016c). İç tüketimde ise Türk gıda kodeksine göre makarnaya ekmeklik buğday kullanılması yasaktır. Bulgur hem makarnalık hem ekmeklik buğdaydan üretilebilmektedir. Türk Gıda Kodeksine göre bulgur (TS 2974'e uygun) buğdayların (Triticum durum, T. aestivum, T. monococcum, T. dicoccon) tekniğine uygun olarak temizlenmesi, pişirilmesi/haşlanması, kurutulması ve istendiğinde kabuğunun ayrılarak kırılması ile elde edilen mamul olarak tanımlanmıştır (Anonim 2009a).

Buğday veriminin artırılmasında tarım tekniğindeki gelişmelerin kullanılmasının yanı sıra yüksek verim potansiyeline sahip çeşitlerin ıslah edilmesi büyük önem taşımaktadır. Yeni geliştirilecek çeşitler de verim ve kalite kayıplarının önlenmesi ya da en az düzeye indirilmesi bakımından bölge de görülen önemli stres faktörlerine karşı dayanıklı ya da toleranslı olmaları gereklidir. Günümüzde hastalıklarla mücadele de ekonomik ve pratik mücadele yollarından birisi de dayanıklı çeşit geliştirilerek bu çeşitlerin üretimde yer almasının sağlanmasıdır (Yazar ve ark. 2013).

Islah çalışmaları ile daha kaliteli, yüksek verimli, hastalıklara ve zararlılara dayanıklı ve yetiştirildiği çevrenin koşullarına uyumlu çeşitler geliştirilmeye çalışılmaktadır. Değişen tüketici tercihleri doğrultusunda farklı kalite özelliklerine sahip buğdaya olan gereksinim her geçen gün daha da artmaktadır (Erkul 2006).

Makarnalık buğdaylarda kalite, genetik yapı, yetiştirildiği yıldaki ekolojik şartlar, yetiştirme tekniği ve bilhassa kullanılan azotlu gübre miktarı ile yakından ilişkilidir. Bazı yıllarda uygun olmayan iklim koşulları kaliteyi olumsuz etkilemektedir. Oysa ülkemizin bazı yerleri ekolojik şartlar bakımından dünyadaki birçok ülkeye göre kaliteli makarnalık buğday üretimine çok elverişlidir. Bunun için makarnalık buğday çeşit geliştirmek için ıslah çalışmalarının yapılması kadar çeşitlerin hangi ekolojide yetiştirilirse daha kaliteli ve verimli olduklarının belirlenmesi ve çeşide özgü yetiştirme tekniklerinin (ekim normu, sıklığı, zamanı ve gübreleme vb.) belirlenmesi çok önemlidir.

\section{Makarnalık Buğday Üretimi}

Dünya makarnalık buğday üretimi 20162017 üretim yılında 40.7 milyon ton olarak gerçekleşmiş ve Türkiye 3.6 milyon ton üretim ile Kanada (7.8 milyon ton) ve İtalya (5.0 milyon ton)'dan sonra Dünya'da 3. ülke olmuştur (Çizelge 1).

Çizelge 1. Dünya makarnalık buğday üretimi ve başlıca üretici ülkeler (Milyon Ton) Table 1. World durum wheat production and major producer countries (Million Tons)

\begin{tabular}{|c|c|c|c|c|c|c|c|c|c|c|}
\hline Ülkeler & $2007 / 08$ & $2008 / 09$ & $2009 / 10$ & $2010 / 11$ & $2011 / 12$ & $2012 / 13$ & $2013 / 14$ & $2014 / 15$ & $2015 / 16$ & $2016 / 17^{*}$ \\
\hline $\mathrm{AB}(28)$ & 8.2 & 10.1 & 8.7 & 9.2 & 8.2 & 8.2 & 8.1 & 7.6 & 8.5 & 9.5 \\
\hline Kanada & 3.7 & 5.5 & 5.4 & 3.0 & 4.2 & 4.6 & 6.5 & 5.2 & 5.4 & 7.8 \\
\hline İtalya & 3.9 & 5.1 & 3.6 & 4.1 & 3.9 & 4.2 & 3.9 & 3.9 & 4.2 & 5.0 \\
\hline Türkiye** & 2.7 & 2.8 & 3.7 & 3.5 & 3.9 & 3.3 & 4.1 & 3.3 & 4.1 & 3.6 \\
\hline ABD & 2.0 & 2.2 & 2.9 & 2.8 & 1.3 & 2.2 & 1.6 & 1.5 & 2.3 & 2.8 \\
\hline Meksika & 1.8 & 2.0 & 2.2 & 2.2 & 2.2 & 2.1 & 2.3 & 2.3 & 2.3 & 2.5 \\
\hline Kazakistan & 3.0 & 2.5 & 2.6 & 1.7 & 3.0 & 1.4 & 2.0 & 2.0 & 2.1 & 2.1 \\
\hline Fransa & 2.0 & 2.1 & 2.1 & 2.5 & 2.1 & 2.4 & 1.8 & 1.5 & 1.8 & 1.6 \\
\hline İspanya & 1.2 & 1.2 & 1.4 & 0.9 & 0.9 & 0.4 & 0.9 & 0.8 & 0.9 & 1.0 \\
\hline Dünya & 34.8 & 38.5 & 41.4 & 35.4 & 37.6 & 35.7 & 38.8 & 34.5 & 39.1 & 40.7 \\
\hline
\end{tabular}

Kaynak: IGC, TMO 2016 Hububat raporu Source: IGC TMO 2016 Cereal report's

Not: AB verileri; 2006/07'den 2012/13'e kadar AB (27), 2013/14 döneminden itibaren AB (28) içindir.

Note: EU data; The EU (27) from 2006/07 to 2012/13 is within the EU (28) from 2013/14. 
Çizelge 2. 2016 Yılı Türkiye bölgelere göre buğday üretimi (Bin Ton) Table 2. Wheat production in Türkiye's regions in 2016 (Thousand Tons)

\begin{tabular}{lcccc}
\hline \multirow{2}{*}{ Bölge Adı } & \multicolumn{2}{c}{ Ekmeklik Buğday } & \multicolumn{2}{c}{ Makarnalık Buğday } \\
\cline { 2 - 5 } & Miktar & $\%$ & 1 & $\%$ \\
\hline Marmara Bölgesi & 2.935 & 17.3 & 468 & 0.0 \\
Ege Bölgesi & 1.087 & 6.4 & 1.397 & 12.9 \\
İç Anadolu Bölgesi & 5.683 & 33.5 & 323 & 38.7 \\
Akdeniz Bölgesi & 1.807 & 10.6 & 27 & 8.9 \\
Doğu Anadolu Bölgesi & 1.148 & 6.8 & 1.294 & 0.7 \\
Güneydoğu Anadolu Bölgesi & 2.425 & 14.3 & 110 & 35.8 \\
Karadeniz Bölgesi & 1.895 & 11.1 & 3.620 & 3.0 \\
\hline Toplam & 16.980 & 100 & 100 \\
\hline
\end{tabular}

Kaynak: TMO 2016 Hububat raporu Source: IGC TMO 2016 Cereal report's

Makarnalık buğday üretiminin bölgeler bazında dağılımı, Çizelge 2'de incelendiğinde İç Anadolu ve Güneydoğu Anadolu Bölgelerinin üretim miktarlarının yakın değerler olduğu görülmektedir Önceki yıllarda en yüksek üretim miktarı Güneydoğu Anadolu Bölgesinde olmaktayken 2016 yılında İç Anadolu bölgesinde üretim artmıştır (Anonim 2016a). İhracatta önemli paya sahip ve üretim kapasitesi fazla olan makarna ve bulgur fabrikalarının büyük çoğunluğunun bu bölgede bulunmasının katkısının olduğu düşünülmektedir. Buna ek olarak Güneydoğu Anadolu Bölgesinde sulanan alanların artışıyla birlikte yatmaya dayanıklı ve yüksek verimli ekmeklik buğdayların yetiştiriciler tarafından daha çok tercih edilmesi ise diğer önemli bir etkendir (Akar 2107).

\section{Makarnalık Buğday Tüketimi}

Makarnalık buğday genellikle tüm buğdayların en sertiolarak düşünülürve iritaneli, sarı amber renkte ve camsıdır. Bu özellikler makarnalık buğdayın protein miktarı ve gluten kalitesiyle pek çok değişik gıdanın üretimine uygun olmasını sağlar. Avrupa ve Kuzey Amerika ülkelerinde makarnalık buğdaydan üretilen en yaygın ürün makarna iken Türkiye, Ortadoğu ve Kuzey Afrika ülkelerinde makarna üretimi yanında bulgur, kuskus, noodle, erişte ve birçok değişik ekmek üretiminde de hammadde olarak kullanılmaktadır (Elias 1995; Liu ve ark. 1996; Troccoli ve ark. 2000).

Makarna kolay hazırlanabilen, besleyici, düşük yağ içerikli, protein kaynağı olan besleyici bir gıdadır. Kuru formda raf ömrünün uzun olması, çok farklı şekillerde tüketilebilmesi (değişik soslar vb.) besleme değerinin yüksek olması ve düşük fiyatı ile tüketicilere cazip gelmektedir (Elias ve Manthey 2005). Dünya da kişi başı makarna tüketiminde $26 \mathrm{~kg}$. ile Italya ilk sırada yer almaktadır. İtalya'yı $13 \mathrm{~kg}$ ile Venezuella ve $11.9 \mathrm{~kg}$ ile Tunus izlemektedir. Türkiye'nin kişi başına makarna tüketimi 1962 yılında 1.2 kg iken, 1978 yılında 3.9, 90'lı yılların başında 4.3 kg'a yükselmiştir. Kişi başına yıllık tüketim artışı devam ederek 2006 yılında 5.8 kg, 2007 yilında 6 kg, 2012 yilında $6.1 \mathrm{~kg}$, 2013 yılında $6,6 \mathrm{~kg}$ ve 2014 yılında ise $7,5 \mathrm{~kg} \mathrm{a}$ çıkmıştır. (Anonim 2017b).

Makarnalık buğdayın ülkemizde en yaygın kullanım şekillerinden biri 4000 yıllık geçmişi olan bulgurdur. Anadolu'da ve Orta Doğu Ülkeleri'nde buğdayın kültüre alındığı dönemden beri üretilmekte olan ve günümüzde de sevilerek tüketilen önemli bir gıda maddesidir (Özboy 1998; Bayram ve Öner 2002). Türkiye'de üretim miktarı ve ekonomik değeri yıllar itibari ile artmaya devam eden bulgur ortalama kişi başına yıllık $12 \mathrm{~kg}$ bulgur tüketilmektedir. Doğu bölgelerinde bu değer 23 $\mathrm{kg}$ iken batı bölgelerinde $7 \mathrm{~kg}$ civarındadır. $\mathrm{Bu}$ üretim artışı, bulgurun yurtdışında da tanınması ile birlikte, ihracatta artışa sebep olmaktadır (Bayram 2000, Bayram ve Öner 2002).

Ülkemiz sanayisinde ve ihracatında önemli bir yeri olan makarna ve bulgurun 2005-2014 yılları arasında gerçekleşen üretim miktarları Çizelge 3 incelendiğinde; makarna üretim miktarımız 2005 yılında 580,5 bin ton iken, 2014 yılında 1202.5 bin tona yükselmiştir. Bulgur üretim miktarları ise 83.1 bin tondan 428.2 bin tona çıkmıştır. Bulgur üretimimizde endüstriyel üretime ek olarak ayrıca yaklaşık bu miktar kadar geleneksel üretim de söz konusudur. 
Pehlivan ve Ünver Ikincikarakaya "Makarnalık Buğdayda Kalite Islahı Çalışmaları"

Çizelge 3. Türkiye'nin 2005-2014 yılları arasında gerçekleşen makarna ve bulgur üretim miktarları (bin ton) Table 3. Pasta and bulgur production amounts (in thousand tons) in Türkiye from 2005 to 2014

\begin{tabular}{ccc}
\hline Yıllar & Makarna Üretimi (bin ton) & Bulgur Üretimi (bin ton) \\
\hline 2005 & 580.5 & 83.1 \\
2006 & 558.5 & 82.8 \\
2007 & 571.3 & 70.5 \\
2008 & 641.0 & 91.9 \\
2009 & 595.2 & 135.3 \\
2010 & 732.4 & 189.0 \\
2011 & 864.0 & 222.2 \\
2012 & 976.6 & 277.5 \\
2013 & 1026.4 & 490.0 \\
2014 & 1202.5 & 428.2 \\
\hline
\end{tabular}

(www.tuik.gov.tr, Erişim tarihi (Date of access): 10.11.2016)

Ülkemizin ihraç ettiği ürünlerin arasında makarna ve bulgur önemli bir yer tutmaktadır. Çizelge 4'te 2004-2016 yılları arasında gerçekleşen ihracat miktar ve değerlerini inceleyecek olursak; makarna ihracat miktarı 2004 yılında 126 bin ton iken, bu değer en fazla 2014 yılında 735 bin ton olarak gerçekleşmiştir. Bulgur ihracat miktarımız ise 2004 yılında 36 bin ton iken, 2016 yılında 179 bin ton olarak gerçekleşmiştir. 2014 yılından sonra makarna ve bulgur ihracat miktarı, ihracat değeri ve ton fiyatında (\$) bir düşüş olduğu görülmektedir. Ayrıca 2008 yılında dışsatım makarna ve bulgur ton fiyatı en yüksek iken 2016 yılında bu fiyatın neredeyse yarıya düştüğü görülmektedir (Çizelge 4).
Makarnalık buğday ekmek yapımında da kullanılmaktadır. Makarnalık buğdayından yapılan ekmek, ekmeklik buğdaydan yapılana göre daha küçük hacimli olmasına rağmen durum buğdayı ekmeği daha sarı renklidir, kendine özgü tat ile kokuya sahiptir ve raf ömrü daha uzundur. Bu özelliklerde bazı tüketiciler için cazip gelmektedir (Atlı ve ark. 2010). Akdeniz bölgesinde ve özellikle güney İtalya'da makarnalık buğday birkaç çeşit ekmekte kullanılmaktadır. Orta Doğu ve Kuzey Afrika'da, toplam makarnalık buğday tüketiminin yaklaşık yarısı ekmek yapımı için kullanılmaktadır (Boyacıoğlu ve D'appolonia 1994).

Çizelge 4. Türkiye'nin 2004-2016 yılları arasında yaptığı makarna ve bulgur ihracat miktarı ve değeri Table 4. Pasta and bulgur exports in quantity and value from Türkiye between 2004 and 2016

\begin{tabular}{|c|c|c|c|c|c|c|}
\hline \multirow[b]{2}{*}{ Yıllar } & \multicolumn{3}{|c|}{ Makarna } & \multicolumn{3}{|c|}{ Bulgur } \\
\hline & $\begin{array}{l}\text { İhracat Miktarı } \\
\text { (ton) }\end{array}$ & $\begin{array}{l}\text { İhracat Değeri } \\
(\$)\end{array}$ & $\begin{array}{l}\text { Ton } \\
(\$)\end{array}$ & $\begin{array}{l}\text { İhracat Miktarı } \\
\text { (ton) }\end{array}$ & $\begin{array}{c}\text { İhracat Değeri } \\
(\$)\end{array}$ & $\begin{array}{l}\text { Ton } \\
(\$)\end{array}$ \\
\hline 2004 & 125.992 & 50.252 .306 & 399 & 36.106 & 14.399 .227 & 399 \\
\hline 2005 & 164.399 & 65.500 .861 & 398 & 68.551 & 24.193 .457 & 353 \\
\hline 2006 & 191.975 & 80.269 .705 & 418 & 56.646 & 21.468 .345 & 379 \\
\hline 2007 & 177.924 & 107.786 .602 & 606 & 73.918 & 37.609 .805 & 509 \\
\hline 2008 & 175.597 & 181.915 .625 & 1.036 & 71.009 & 56.977 .972 & 802 \\
\hline 2009 & 213.506 & 149.422 .907 & 700 & 115.227 & 63.209 .287 & 549 \\
\hline 2010 & 297.280 & 185.888 .023 & 625 & 160.649 & 80.024 .511 & 498 \\
\hline 2011 & 404.039 & 285.261 .094 & 706 & 122.443 & 70.297 .089 & 574 \\
\hline 2012 & 505.569 & 357.800 .281 & 708 & 122.678 & 69.502 .330 & 567 \\
\hline 2013 & 693.101 & 493.928.791 & 713 & 159.990 & 97.157 .211 & 607 \\
\hline 2014 & 735.027 & 506.857 .171 & 690 & 211.485 & 122.644 .507 & 580 \\
\hline 2015 & 671.837 & 417.993 .472 & 622 & 199.831 & 101.152 .562 & 506 \\
\hline $2016^{*}$ & 629.465 & 323.630 .902 & 514 & 178.678 & 71.412 .721 & 400 \\
\hline
\end{tabular}


Ülkemizde ise farklı isimlerde üretilen ekmeklerde makarnalık buğday unu kullanılmaktadır. Yapılacak ekmek çeşidine göre makarnalık buğday unu, ekmeklik un veya tam buğday unu ile paçal yapılarak ekmek yapımında kullanılmaktadır. Ayrıca baklava, kadayıf yapımında ürüne parlak renk verebilmesi, tazeliğini ve gevrekliğini uzun süre koruması ve lezzeti artırması sebebiyle makarnalık buğday unu belli oranlarda ilave edilerek kullanılmaktadır. Marketlerde pasta, börek ve baklavalık olarak satılan bazı özel amaçlı unlarda da belli oranlarda makarnalık buğday unu bulunmaktadır.

\section{Ülkemizdeki Makarnalık Buğday Çeşitleri}

Ülkemizde Gıda Tarım ve Hayvancılık Bakanlığına bağı Tohumluk Tescil ve Sertifikasyon Merkez Müdürlüğü (TTSMM) çeşitlerin tescil ve tohumlukların kontrol ve sertifikasyonu ile ilgili çalışmaları gerçekleştirilmektedir. Yeni çeşit adayları ile ilgili tarla ve laboratuvar testlerini (farklılık, yeknesaklık, durulmuşluk ve tarımsal değerleri ölçme)yaparakyurtiçindeveyayurtdışında ıslah edilen yeni bitki çeşitleri ile yurt dışından ithal edilen çeşitlerin tescilini yapmak, yurt içi amaçlı üretimlerde etiket düzenlemek tescil edilen veya üretim izni verilen ve Milli Çeşit Listesinde yayımlanan çeşitlere ait tohumlukların kontrol ve sertifikasyonu ile ilgili çalışmalar bu kurum tarafından gerçekleştirilmektedir (Anonim 2017a).
2017 yılı Milli Çeşitler Listesi'nde 75 adet tescilli makarnalık buğday çeşidi bulunmaktadır. Ayrıca üretim izinli 11 çeşit bulunmaktadır (tescil denemeleri süresince üretim izni verilmektedir). Şekil 1'de Milli Çeşit listesinde yer alan makarnalık buğday çeşitlerinin tescil edildiği yıllara ve çeşitlerin sahibi kurumlara göre dağılımı görülmektedir. Kamu başlı̆ı altında araştırma enstitüleri, üniversiteler başlığı altında Ziraat Fakülteleri ve özel sektör tohumluk üretici kuruluşları çeşit sayıları incelendiğinde son yıllarda özel sektör tarafından tescil ettirilen çeşit sayısının arttığı görülmektedir. Bu artış Gıda Tarım ve Hayvancııık Bakanlığının sertifikalı tohum üretimine ve kullanımına verdiği destekler sayesinde gerçekleşmiştir (Anonim 2017c).

Çizelge 5. incelendiğinde Tarımsal Araştırmalar ve Politikalar Genel Müdürlüğüne bağlı araştırma enstitülerinin 44 üniversitelerin ise 6 makarnalık buğday çeşidini tescil ettirdiği görülmektedir. Dicle Üniversitesi Ziraat Fakültesi tarafından tescil ettirilen Sena çeşidi ise Milli çeşit listesinde bulunmamaktadır. Milli çeşit listesinde yer alan özel sektör tohumluk üretici kuruluşlarına ait 25 çeşidin büyük çoğunluğu daha önce yurt dışında tescil edilmiş çeşitler olduğu görülmektedir. Yurt dışında çok eski yıllarda tescil edilmiş çeşitlerin ülkemize getirilerek tescil ettirilmesi makarnalık buğday özel sektör tohumluk üretici kuruluşlarında yapılan bir uygulama şekli olmuştur. Örneğin 2000 yılında İtalya'da ıslah edilen bir çeşit 2017 yılında ülkemizde tescil edilmiştir (Anonim 2017c).

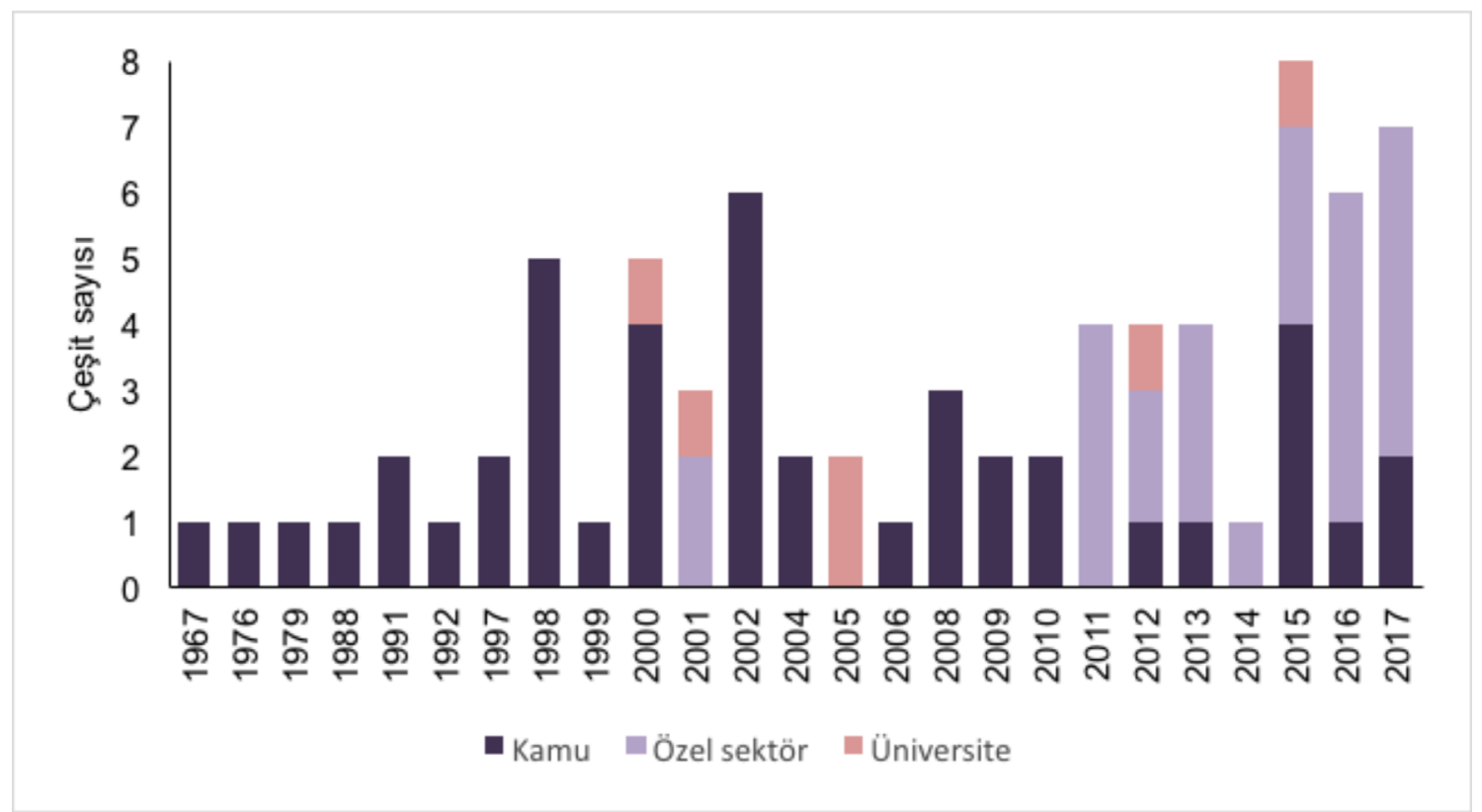

Şekil 1. 1967-2017 yılları arasında tescil edilen makarnalık buğday çeşitlerinin sayısı

Figure 1. Number of the wheat varieties registered between 1967 and 2017 
Pehlivan ve Ünver İkincikarakaya "Makarnalık Buğdayda Kalite Islahı Çalışmaları"

Çizelge 5. 2017 TTSMM Milli Çeşit Listesindeki makarnalık buğday çeşitlerinin tescil tarihleri ve ait olduğu kuruluşlar

Table 5. Durum wheat varieties listed in the 2017 VRSCC National Variety List registration dates and maintainer of the varieties

\begin{tabular}{|c|c|c|c|}
\hline & Çeşit Adı & Tescil Tarihi & Başvuru Sahibi \\
\hline 1 & Selçuklu-97 & 06.05 .1997 & Bahri Dağdaş Uluslararası Tarımsal Araştırma Enstitüsü \\
\hline 2 & Meram-2002 & 02.05 .2002 & Müdürlüğü - Konya \\
\hline 3 & Sham-1 & 26.04.1991 & \multirow{7}{*}{$\begin{array}{c}\text { Doğu Akdeniz Tarımsal Araştırma Enstitüsü } \\
\text { Müdürlüğü - Adana }\end{array}$} \\
\hline 4 & Amanos-97 & 06.05.1997 & \\
\hline 5 & Fuatbey 2000 & 28.04.2000 & \\
\hline 6 & Sarı Başak & 12.04.2013 & \\
\hline 7 & Eker & 26.03.2015 & \\
\hline 8 & Ayzer & 26.03.2015 & \\
\hline 9 & Günberi & 13.04.2017 & \\
\hline 10 & Gediz-75 & 13.05.1976 & \multirow{9}{*}{$\begin{array}{l}\text { Ege Tarımsal Araştırma Enstitüsü } \\
\text { Müdürlüğü - İzmir }\end{array}$} \\
\hline 11 & Ege 88 & 26.04 .1988 & \\
\hline 12 & Salihli 92 & 12.05 .1992 & \\
\hline 13 & Şölen 2002 & 02.05 .2002 & \\
\hline 14 & Tüten 2002 & 02.05 .2002 & \\
\hline 15 & GAP & 01.04.2004 & \\
\hline 16 & Turabi & 01.04.2004 & \\
\hline 17 & Alatay & 26.03 .2015 & \\
\hline 18 & Yaren & 14.04.2016 & \\
\hline 19 & Akçakale-2000 & 02.05 .2002 & \multirow{3}{*}{$\begin{array}{l}\text { GAP Tarımsal Araştırma Enstitüsü } \\
\text { Müdürlüğü -Şanlıurfa }\end{array}$} \\
\hline 20 & Gündaş & 17.04.2012 & \\
\hline 21 & Edessa 63 & 13.04.2017 & \\
\hline 22 & Altıntoprak 98 & 12.05 .1998 & \multirow{10}{*}{$\begin{array}{c}\text { GAP Uluslararası Tarımsal Araştırma ve Eğitim Merkezi } \\
\text { Müdürlüğü - Diyarbakır }\end{array}$} \\
\hline 23 & Sarı çanak 98 & 12.05 .1998 & \\
\hline 24 & Aydın-93 & 02.05 .2002 & \\
\hline 25 & Fırat-93 & 02.05 .2002 & \\
\hline 26 & Artuklu & 02.04 .2008 & \\
\hline 27 & Eyyubi & 02.04 .2008 & \\
\hline 28 & Şahinbey & 02.04 .2008 & \\
\hline 29 & Zühre & 30.03 .2010 & \\
\hline 30 & Güney Yıldızı & 30.03 .2010 & \\
\hline 31 & Hasanbey & 26.03.2015 & \\
\hline 32 & Kunduru 1149 & 26.04 .1967 & \multirow{4}{*}{$\begin{array}{c}\text { Geçit Kuşağı Tarımsal Araştırma Enstitüsü } \\
\text { Müdürlüğü - Eskişehir }\end{array}$} \\
\hline 33 & Kümbet 2000 & 28.04 .2000 & \\
\hline 34 & Yelken 2000 & 28.04 .2000 & \\
\hline 35 & Dumlupınar & 14.04 .2006 & \\
\hline 36 & KızıItan 91 & 26.04 .1991 & \multirow{8}{*}{$\begin{array}{l}\text { Tarla Bitkileri Merkez Araştırma Enstitüsü } \\
\text { Müdürlüğü - Ankara }\end{array}$} \\
\hline 37 & Altın 40/98 & 12.05.1998 & \\
\hline 38 & Ankara 98 & 12.05.1998 & \\
\hline 39 & Yılmaz 98 & 12.05 .1998 & \\
\hline 40 & Çeşit-1252 & 26.04.1999 & \\
\hline 41 & Mirzabey 2000 & 28.04 .2000 & \\
\hline 42 & Eminbey & 06.04.2009 & \\
\hline 43 & İmren & 06.04.2009 & \\
\hline 44 & Tunca 79 & 15.05 .1979 & Trakya Tarımsal Araştırma Enstitüsü Müdürlüğü - Edirne \\
\hline 1 & Balcalı 2000 & 28.04 .2000 & \multirow{2}{*}{$\begin{array}{l}\text { Çukurova Üniversitesi Ziraat Fakültesi } \\
\text { Uludağ Üniversitesi Ziraat Fakültesi }\end{array}$} \\
\hline 2 & Pınar-2001 & 24.04 .2001 & \\
\hline 3 & Özberk & 30.03 .2005 & \multirow{2}{*}{ Harran Üniversitesi Ziraat Fakültesi } \\
\hline 4 & Urfa 2005 & 30.03 .2005 & \\
\hline 5 & Soylu & 17.04.2012 & Selçuk Üniversitesi Ziraat Fakültesi \\
\hline 6 & NKÜZiraat & 26.03.2015 & Namık Kemal Üniversitesi Ziraat Fakültesi \\
\hline
\end{tabular}


Çizelge 5. devamı

Table 5.continued

\begin{tabular}{llll}
\hline & Çeşit Adı & Tescil Tarihi & Başvuru Sahibi \\
\hline 1 & Tripudio & 14.04 .2016 & \multirow{2}{*}{ Aksoy Turizm ve Gıda San. Tic. Ltd. Şti. } \\
\hline 3 & Trionfo & 14.04 .2016 & \\
\hline 4 & Tiziana & 13.04 .2017 & Alfa Toh. Tar. Gıd. İnş. Hay. Paz. San. Tic. Ltd. Şti \\
5 & Zitka & 17.04 .2012 & \\
6 & Massimo Meridio & 11.04 .2014 & Ata Tohumculuk İşı.San. ve Tic.A.Ş. \\
\hline 7 & Burgos & 08.04 .2011 & Fito Tohumculuk Ticaret Ltd. Şti. \\
\hline 8 & Uniya & 26.03 .2015 & Marmara Tohum Geliştirme A.Ş. \\
9 & Zolotko & 13.04 .2017 & \\
\hline 10 & Casanova & 12.04 .2013 & \multirow{2}{*}{ Maro Tarım İnş. Tic. Ve San. A.Ş. } \\
11 & Pitagora & 12.04 .2013 & \\
\hline 12 & Perre & 26.03 .2015 & Olgunlar Turizm Tarım Enerji Üretim Tic. Pazrım. Ltd. Şti. \\
\hline 13 & Mimmo & 13.04 .2017 & Pioneer Tohumculuk Dağ ve Paz.Ltd. Şti. \\
\hline 14 & Claudio & 08.04 .2011 & \\
15 & Cesare & 12.04 .2013 & Progen Tohum A.Ş. \\
16 & Troubadur & 13.04 .2017 & \\
17 & Ecem & 13.04 .2017 & \\
\hline 18 & Svevo & 24.04 .2001 & \\
19 & Zenit & 24.04 .2001 & \\
20 & Levante & 08.04 .2011 & Tasaco Tarım Sanayi ve Tic.Ltd.Şti. \\
21 & Saragolla & 08.04 .2011 & \\
22 & Maestrale & 26.03 .2015 & \\
\hline 23 & Bisante & 17.04 .2012 & \multirow{2}{*}{ Trakya Tarım ve Vet Tic. Ltd.Şti. } \\
24 & Nova & 14.04 .2012 & \\
25 & Ganos & 14.04 .2012 & \\
\hline & & & \\
\hline
\end{tabular}

Çizelge 6. 2017 TTSMM *üretim izinli makarnalık buğday çeşitlerinin izin tarihleri ve ait olduğu kuruluşlar Table 6. Permitted durum wheat varieties of listed in the 2017 VRSCC National Variety List permission dates and maintainer of the varieties

\begin{tabular}{llll}
\hline & Çeşit Adı & Üretim İzni Tarihi & Başvuru Sahibi \\
\hline 1 & Argeles & 31.08 .2015 & Alfa Toh. Tar. Gıd. İnş. Hay. Paz. San. Tic. Ltd. Şti \\
2 & Salgado & 26.08 .2016 & Alfa Toh. Tar. Gıd. İņ. Hay. Paz. San. Tic. Ltd. Şti \\
3 & Reglisse & 31.08 .2015 & Caso Tohum San. Ve Tic. Ltd. Şti \\
4 & Vicktoriya & 26.08 .2016 & Dobruca Tohumculuk San Tic. Ltd. Şti. \\
5 & Mercan & 26.08 .2016 & Hazera Tohumculuk ve Tic. A.Ş. \\
6 & Duronesse & 26.08 .2016 & LT Tarım Üretim Paz. Tic. Ltd.Şti. \\
7 & Anzele & 26.08 .2016 & Orhas İç ve Dış Tic. Ltd. Şti. \\
8 & Milandur & 31.08 .2015 & ProGen Tohum A.Ş. \\
9 & Ovidio & 26.08 .2016 & ProGen Tohum A.Ş. \\
10 & Ginseng & 26.08 .2016 & Semila Tohumculuk San ve Tic. Ltd. Şti. \\
11 & Mario & 30.09 .2016 & Syngenta Tarım Sanayi Ve Ticaret A.Ş. \\
\hline
\end{tabular}

*Üretim izni tescil denemeleri süresince verilmektedir

${ }^{*}$ The production permit is issued during the registration trials

\section{Makarnalık Buğday Islahı ve Yöntemleri}

Bitkilerde; genetik ve sitogenetik esaslardan yararlanarak bitki cins, tür ve çeşitlerinin genetik yapısını üretici ve tüketicinin istekleri doğrultusunda değiştirme ve geliştirme bilim ve sanatı bitki ıslahı olarak tanımlanmaktadır (Ünver 2016).
Makarnalık buğday ıslah çalışmalarının amacı; üretici için verimi yüksek ve hastalıklara dayanıklı, sanayici için son ürüne (makarna, bulgur vb.) ve tüketici için ise tüketim isteğine uygun kalitede çeşit geliştirmektir. Yeni çeşit geliştirme sürecinde görev alan birimlerin (buğday ıslahçıları, hastalıkçıları ve tahıl kalitecileri) başarısı, geliştirdikleri 
yeni çeşitlerin üretici, sanayici ve tüketici tarafından benimsenme oranı ile ölçülür. Kalite özelliklerinin çoğu, çeşidin genetik yapısı ile ilgili olmasına karşın, bazıları (protein miktarı gibi) çevre şartlarından etkilendiğinden, çeşit geliştirme programlarında kalıtsal özelliklerin saptanabildiği kalite testlerinin uygulanması ve doğru kalite analizinin seçilebilmesi için de kaliteyi etkileyen faktörlerin bilinmesi gerekir (Ozan 2004).

Makarnalık buğday ıslah çalışmaları ile uzun boylu olan makarnalık buğdaylarda boy kısaltıımış, sap sağlamlığı arttırılmış ve yüksek verim potansiyeline sahip makarnalık buğdaylar geliştirilmiştir (Yazar ve Karadoğan 2008).

Makarnalık buğdaylar tetraploid $2 n=4 x=28$, AABB genomuna sahip bir buğday türüdür. Kalite bakımından taleplerin karşılanabilmesi için kalite ile ilgili genetik çeşitliliğin artırılması ve bunun ıslahta kullanılması gereklidir. Sissons ve Hare (2002) makarnalık buğdayların tetraploid akrabalarının faydalı bir gen kaynağı olabileceğini ve tetraploid buğdayların alt türlerinin (T. turgidum var. durum, polonicum, persicum, turanicum, turgidum) kalitenin belirlenmesinde ana faktörler olan tanede protein içeriği ve kompozisyonu bakımından geniş bir değişim gösterdiğini vurgulamışlardır.

Bitkilerin kalıtımında kalitatif ve kantitatif karakterler rol oynamaktadır. Kalitatif Karakterler. Tek genle kontrol edilen, basit kalıtsal karakterlerdir. Bunlar, major genler olarak da bilinir. Kavuz rengi ve tüylülük durumu, kılçıklılık gibi, gözle görülebilen fenotipik ve genotipik özelliklerin eşit olduğu karakterlerdir. $\mathrm{Bu}$ karakterler çevre koşullarında ya hiç etkilenmez ya da çok az etkilenir. Açılımlarında baskınlık (dominantlık) hakimdi. Kantitatif Karakterler. Çok genle kontrol edilen, çevre koşullarından etkilenen, sayılarak, tartılarak ölçülerek ya da kimyasallarla etkileşmeleri sonucu belirlenebilen özelliklerdir. Kalıtımları karmaşıktır ve değişiklikler (modifikasyon) olabilmektedir. Bu nedenle beklenen özellikleri tahmin etmek güçtür ve açılım oranları çok yüksektir (Ünver 2016).

Buğday ıslahı çalışmalarında genellikle üzerinde ağırlıkla durulan karakterler, çok gen tarafından idare edilen ekonomik öneme sahip kantitatif (verim ve kalite gibi) karakterlerdir. Ancak bu karakterler çevre şartlarından oldukça fazla etkilenmektedir (Sissons ve Hare, 2002). $\mathrm{Bu}$ nedenle, çevre şartlarından etkilenmeyen seleksiyon kriterlerinin bulunması genetik ilerlemeyi ve iyileştirmeyi hızlandıracaktır (Bilgin 2001).

Buğday ıslahında birçok yöntemden yararlanılmakta olup, her geçen gün yeniözellikler taşıyan çeşitlerle verim ve kalite artışına katkıda bulunulmaktadır. Uygulanan ıslah yöntemleri çeşit getirme (introdüksiyon) seleksiyon, mutasyon melezleme ve genetik modifikasyon olarak sıralanmaktadır (Akar 2017).

\section{Çeşit Getirme (İntrodüksiyon)}

Ekonomik önemi olan bitkilerin bir ülkeden başka bir ülkeye taşınması ve yetiştirilmesi introdüksiyon olarak tanımlanır (Ünver 2016). İntrodüksiyon materyalinin adaptasyon denemelerinin farklı yetiştirme koşullarında yapılması sonuçta da istenilen başarının elde edilmesi için önemlidir. Ülkemizde yazlık dilim kuşağında yetiştirilen özel sektör tohumluk üretici kuruluşlarına ait mevcut tescilli makarnalık buğday çeşitlerinin büyük çoğunluğu diğer ülkelerde ıslah edilmiş olan çeşitler olup doğrudan doğruya üretim amacıyla introdüksiyon materyali olarak getirilmişlerdir.

\section{Seleksiyon}

Üniform olmayan materyal içerisinden uygun olan bitkilerin seçilmesidir. Genellikle gen kaynağı olan türlerde uygulanan bir yöntem olup karışık populasyon, yerel çeşitler, doğal mutasyona uğramış farklı materyalden amaca uygun bitki ya da bitki gruplarının seçimine dayanan bir Islah yöntemidir. Teksel (saf hat) seleksiyon, toptan (mass) seleksiyon ve değiştirilmiş toptan seleksiyon şeklinde uygulanabilir (Ünver 2016). Seleksiyon çalışmalarında, çeşit ıslahının uzun yıllar sürmesi başlıca sorun olup, olası salgın bir hastalığa karşı kısa sürede çözüm üretilemez (Şehirali ve Özgen 1988).

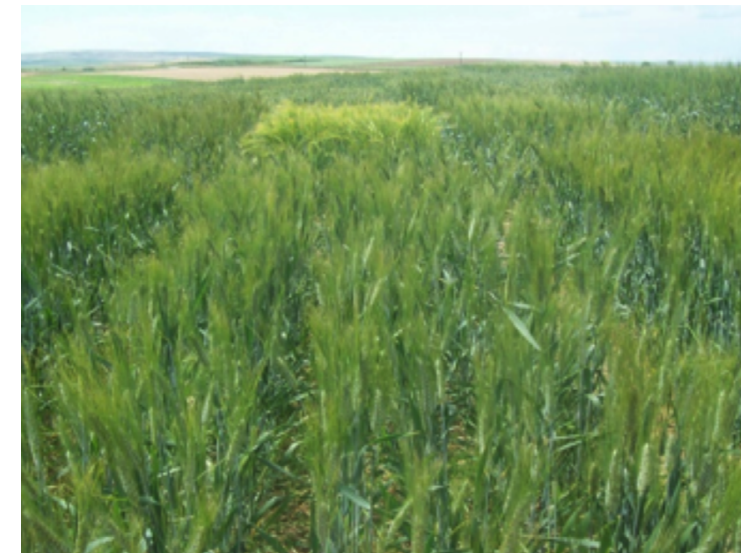

Şekil 2.Tarla denemelerinden bir görünüm Figure 2. A view of the field experiments

Fotograf Aliye Pehlivan'a aittir

Photo was taken by Aliye Pehlivan 


\section{Mutasyon}

Mevcut çeşit veya hattın bir ya da iki özelliği iyileştirilmek istendiğinde mutasyonlar bitki ıslahında kullanılmaktadır. Mutagenler ile genetik materyal üzerinde ne gibi bir değişiklik olacağı kesin olarak önceden bilinememektedir. Elde edilen bu mutantlarda amaca uygun olarak yeniden seleksiyonların uygulanması gerekmektedir. Ayrıca mutant bitkilerde morfolojik ve fizyolojik birçok aksaklıklar da ortaya çıkabilmekte ve böylece bitkinin gelişmesi yavaşlamaktadır. (Şehirali ve Özgen 1988). Çiftçi ve Şenay (2005) Mutasyon tekniği kullanılarak yapılan bitki ıslahı çalışmalarında mutagen uygulamalarından düşük fizyolojik zarar ve yüksek mutasyon frekansının (populasyonda varyasyonun geniş olması) ortaya çıkmasının istendiğini bildirmişlerdir.

\section{Melezleme}

Melezleme iki ya da fazla sayıdaki çeşit, hat ya da türde bulunan ve istenen özellikleri tek bir çeşitte toplamak amacıyla yapılır. Melezleme ile genetik faktörlerin oluşturduğu yeni kombinasyon, anaçlarda bulunmayan yeni ve istenen karakterleri ortaya çıkarabilir. Melezleme ıslahının aşamaları anaçların seçimi, anaçların yetiştirilmesi, kısırlatma (kastrasyon), toz verme ve yalıtımdır (izolasyon). Melezleme aşamaları Şekil 3'te görülmektedir. Melezlemede kısırlatmadaki zorluklar ve uzun yıllar seçmelerin yapılması önemli sorunlardandır

Islah çalışmalarında geleneksel ıslah tekniklerine yeni bitki biyoteknolojik metotlar da entegre edilmeye başlanmıştır. Islah çalışmalarını kolaylaştırmak ve sonuca daha çabuk ulaşılabilmek; ikiye katlanmış (doubled haploid) hatların kullanılmasıyla mümkün olabilmektedir. Buğdayda homozigot hatların üretiminde anter kültürü gibi özel doku kültürü metotları etkili olabilmektedir. Buğdayda invitro androgenesis yoluyla tek bir generasyonla homozigot hatlar geliştirilmektedir. Bu yöntemle ıslahçıların melezlemeden sonra homozigot hatlar elde etmek için harcadıkları süre en az 4-5 yıl azalmakta, bu da ıslahçılara oldukça fazla bir zaman tasarrufu sağlamaktadır. Ayrıca homozigot hatlar tarla denemelerinde daha gerçekçi agronomik performans göstermekte ve daha etkili bir seleksiyon yapılabilmektedir (Salantur ve ark. 2011).

Makarnalık buğday ıslah çalışmalarında ıslahçı melezleme öncesinde melez bahçesindeki materyalinin kalitesine ve özelliklerini bilerek melezleme yapmaktadır. Melezleme sonrasında elde edilen $\mathrm{F}_{1}$ tohumları 2. yıl ekilir. $F_{1}$ 'lerin yetiştirilmeye başlamasıyla yetiştirilme koşullarında (soğuk, kurak, sıcaklık vb.) doğal seleksiyona tabii olmaktadır. 3. yıl ekilen $F_{2}$ generasyonunda negatif seleksiyon
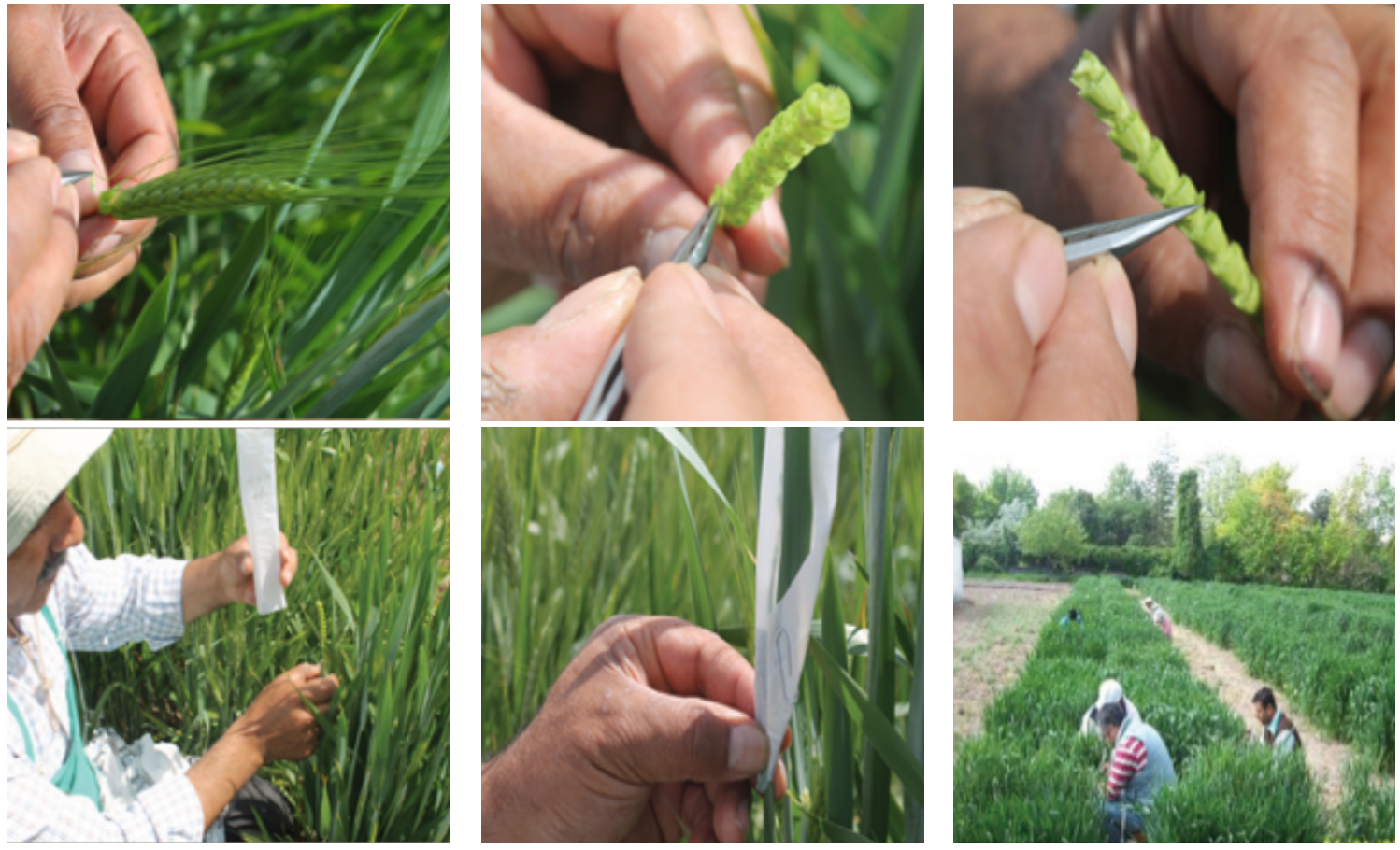

Şekil 3. Melezleme aşamaları

Figure 3. Hybridization stages

Fotoğraflar Tarla Bitkileri Merkez Araştırma Enstitüsü buğday ıslah bölümüne aittir

Photos were taken by wheat breeding department in Field Crops Central Research Institute 
yapılmaya başlanır. $\mathrm{F}_{3}$ ve $\mathrm{F}_{4}$ generasyonlarında da ıslahçı seleksiyon yapmaya devam eder. $\mathrm{F}_{5}$ 'in yetiştirildiği 6 . yıl tek başak seçmeleri yapılır çünkü bu aşamada \%98 homozigotluğun olduğu kabul edilir. $F_{6}$ ve $F_{7}$ aşamalarında ön verim denemeleri kurularak hatların hastalık ve kalite yönüyle değerlendirmeleri başlamaktadır (Salantur 2013).

Ön verim denemeleri genelde Augmented deneme deseninde düzenlenir. Denemede mutlaka verim ve kalitesi çok iyi olan standart çeşitler bulunmalıdır. Standart çeşitlerin (kalite, verim ve hastalık) sonuçlarına göre hatlar değerlendirilerek bir sonraki ıslah kademesi olan ileri kademe verim denemelerine alınır. İleri kademe verim denemeleri tekrarlı olarak (tesadüf blokları deneme deseni gibi) gerçekleştirilir. Denemeler 2 - 3 lokasyonda yürütülür.

İleri kademe hatlarının farklı çevrelerde yetiştirilmesi yüksek verim ve kalite özelliklerine sahip çeşitlerin geliştirilmesi için gereklidir. Verim ve kalitenin değişik çevre koşullarındaki değişimi tespit edilerek istenen verim ve kalite özellikleri bakımından stabil olan hatlar çeşit adayı olarak değerlendirilebilir (Yazar ve ark. 2013)

İleri kademe verim denemelerinden iyi olarak seçilen hatlar farklı özelliklere sahip (kurak, soğuk vb) en az 5-6 lokasyonda bölge verim denemeleri kurularak yetiştirilir. Islahçı verim, kalite ve hastalık yönüyle hatları değerlendirerek çok iyi özellik gösteren hattı tescil edilmesi için TTSMM'ye başvuruda bulunabilir.

\section{Makarnalık Buğdayda Kalite Islahı}

Makarnalık buğday ıslahında makarna sanayinin özellikle üzerinde durduğu kalite kriterleri; fiziksel özellikler yanında, protein miktar ve kalitesi ile irmikte b sarılık değeridir (Atlı ve ark. 2010). Makarnalık buğdayın kalitesinin değerlendirilmesinde TS 2974 buğday standartı ve TMO makarnalık buğday alım baremindeki derecelendirme faktörleri düşünülebilir. Her iki sistemdeki derecelendirme ve gruplama (sınıflama) faktörleri benzer parametrelerdir. Islah çalışmalarındaki kalite analizlerinde temizlenmiş numune kullanıldığından kırık tane vb. derecelendirme kriterleri kalite değerlendirmesinde kullanılmaz. $\mathrm{Bu}$ derecelendirme faktörlerinden Hektolitre ağırığı, kısmen veya tamamen dönmeli tane oranı (camsı tane oranı), protein oranı ıslah çalışmalarında önemlidir. Süne emgi zararı kaliteyi olumsuz yönde etkilediğinden denemelerin süne mücadelesinin en uygun şekliyle yapılması çok önemlidir. Hastalık ve zararlılar olabilecek optimum kaliteyi değiştireceği için doğru değerlendirme yapılamaz. Ayrıca denemelerin agronomik uygulamaları zamanında, uygun dozda. homojen ve dikkatli yapılması çok önemlidir. Gübrelemenin homojen yapılmaması hatların protein oranı gibi kalite değerlerinin doğru belirlenememesine neden olabilecektir.

Makarnalık buğday ıslahında kalite değerlendirmesindeki önemli parametreler ile ıslah kademelerine göre bu parametrelerin nasıl yorumlanacağı aşağıda açıklanmaktadır.

\section{Bin Tane Ağırlığı}

Bin tane ağırlığı; bin tanenin gram cinsinden ağırlığı olup kurumadde olarak belirtilmektedir (Köksel ve ark. 2000). Genetik özellikler ve çevre koşullarından etkilenen bir kalite kriteridir ve yüksek olması istenir. Bin tane ağırlığı fazla olduğu takdirde endospermin kepeğe oranı da artmakta ve dolayısıyla irmik ya da bulgur verimi yüksek olmaktadır. Tanelerin kırışık ve cılız oluşu bin tane ağırlığını azaltmaktadır. Çevre şartlarının olumsuzluğu sonucu dönmeli, olgunlaşmamış ve buruşuk tane irmik verimini ve irmik partikül iriliğini azaltmaktadır. Atlı ve ark. (1993) yaptığı bir çalışmada 12 makarnalık buğday çeşidinin bin tane ağırlığının 10 farklı bölgede ve 10 yı sonuçlarının 37.0-42.9 g arasında Şahin ve ark. ise 29.80 - $39.60 \mathrm{~g}$ (ortalama $35.68 \mathrm{~g}$. değişim gösterdiğini belirlemişlerdir. Türkiye'de genellikle makarnalık buğdaylarda ise 25$55 \mathrm{~g}$ arasında değişmektedir (Köksel ve ark. 2000) Bin tane ağırlığının kalıtım derecesini belirlemek için yapılan çalışmalarda 0.81 (Tsegaye ve ark.2012), 0.41 (Bilgin ve ark. 2010), 0.35 (Akçura 2009) gibi farklı sonuçlar belirlemişlerdir.

\section{Hektolitre Ağırlığı}

Birim hacmin ağırlığı olan hektolitre ağırlığı makarnalık buğdayının kalitesinin belirlenmesinde kullanılan en yaygın ölçülerden birisidir. Tanenin şekli, boyutu, yoğunluğu, ve homojenliği etkilemektedir (Boyacıoğlu ve Tülbek 2002). Ülkemizde ve birçok ülkenin buğday standartlarında yer alan en önemli derecelendirme faktörüdür. Hektolitre ağırlığı öğütme kalitesinin bir göstergesidir ve genelde irmik verimi ile hektolitre ağırığı arasında pozitif korelasyon vardır (Pomeranz 1998). Hektolitre ağırlığı kalıtım, yetiştirme tekniği ve 
iklim koşullarına bağlı olarak değişmektedir. Yaptıkları çalışmalarda hektolitre ağırlığı kalıtım derecesini 0.293 (Bilgin ve ark. 2010), 0.29 (Budak 2000) olarak belirlemişlerdir. Hektolitre ağırlığının yüksekliği aynı zamanda buğdayın sağlam ve hastalıklı tanelerden ari olduğunu göstermektedir (Atlı ve ark. 2010). Buğday bitkisinde generatif devrenin çok kurak ve sıcak geçmesi tanede yeterli besin maddesi birikiminin gerçekleşmesini önlemekte ve hektolitre ağırlığının düşmesine neden olmaktadır.

TMO makarnalık buğday 2016 alım bareminde $78 \mathrm{~kg} / \mathrm{hl}$ ve üzeri 1. grup, 77,9-76,0 2. grup, $75,9-74,0$ 3. grup ve 73,9 ve alt düşük vasıflı sınıfta fiyatlandırılıp depolanmaktadır (Anonim 2016a).

\section{Camsı Tane Oranı}

Camsı tane; dış görünüşünde veya kesitinde unlu leke bulunmayan sıkı ve sert yapılı, camsı görünüşlü taneler olarak tanımlanmaktadır. Camsı, kısmen veya tamamen dönmeli tane oranı makarnalık buğday sınıflandırma ve fiyatlandırmada yaygın kullanılan bir kalite parametresidir. Camsı tane oranı arttıkça irmik verimi ve makarna kalitesi de artmaktadır. İrmik öğütme esnasında genellikle camsı taneden daha iri irmik ve daha az un elde edilmektedir (Aktan ve Atı, 1993). Camsı tane oranı çeşit özelliği ve yetiştirme koşullarından etkilenen bir kalite parametresidir. Tane dolum döneminde yağışlı, serin ve nemli çevre koşullarında camsı tane oranı azalmaktadır (Kün 1988). Ayrıca topraktan alabilecek azotun miktarı makarnalık buğdaylarda kısmen veya tamamen dönmeli tane oranını etkilemektedir (Melik 2014). Yapılan çalışmalarda kalıtım derecesi 0.23 (Tsegaye ve ark.2012) ve 0.391 (Bilgin ve ark. 2010) oranları belirlenmiştir. TMO makarnalık buğday 2016 alım bareminde kısmen veya tamamen dönmeli tane oranı 0-20 1. grup, 21-35 2. grup ,36-50 3. grup ve 50 üzeri düşük vasıflı grupta fiyatlandırılıp depolanmaktadır (Anonim 2016a).

Atlı ve ark. (1993) 10 farklı bölgede yetiştirilen 12 adet makarnalık buğday çeşidinin 10 yıl kalite analizlerini yapmış ve çalışma sonucunda bin tane ağırlığı, hektolitre ağırlığı, camsı tane oranı ve protein oranı kalite değerlerine iklim özelliklerinin önemli rol oynadığını belirlemişlerdir.

\section{Protein Miktarı ve Kalitesi}

Buğdayda protein miktarı ve kalitesi en önemli kalite parametrelerindendir. Protein oranı çeşidin genetik potansiyeli, agronomik uygulamalar (gübreleme vb.) ve çevresel faktörlere bağlı olarak değişmektedir (Atlı 1985). Protein kalitesinin çevresel ve agronomik uygulamalardan fazla etkilenmediği kalıtsal bir özellik olduğu ortaya konmuştur (Borghi ve ark 1997; Miadenow ve ark 2001). Protein oranında yapılan çalışmalarda kalıtım derecesini 0.50 (Tsegaye ve ark.2012), 0.321 (Bilgin ve ark. 2010), 0.399 (Akçura 2009), 0.64 (Budak 2000), Levy ve Feldman (1989) ise 0.29 - 0.53 arasında bulmuşlardır. Gluten proteinlerinin vizkoelastik ve kohezif özellikleri büyük oranda genotipe bağlı olarak değişmektedir (Clarke ve ark. 1998).

Protein oranı makarnalık buğday sınıflandırma ve fiyatlandırmada çok önemlidir. TMO'nun 2016 makarnalık buğday alım bareminde, fiyat 1000 lira/ton olarak belirtilmiş ve protein oranlarına göre \%7'ye kadar ilave fiyatta artış yapılacağı yer almıştır. Protein oranı 13.5-15 ve üzeri 1. grup, 13.4-12.5 2. grup, 12.4-11.5 3. Grup ve 11.4 ve altı düşük vasıflı olarak gruplandırılmaktadır. Ayrıca makarnalık buğday ticaretinde işlem yapılan borsalar vb.de protein oranı fiyatı etkilemektedir. Lisanslı depoculuk sisteminde de sınıflama elektronik ürün senetleri ve depolama TMO alım baremindeki kriterlere göre yapılmaktadır (Anonim 2016a). Bu durum buğday yetiştiriciliğinde protein miktarına etki eden faktörleri daha önemli bir hale getirmiştir. Islah çalışmalarında ise denemelerde aynı koşullarda yetiştirilen hatların içinde yüksek protein oranına sahip olanların seçilmesi daha önemli olmuştur.

Buğdaylarda protein oranı iklim, toprak ve çeşide bağlı bir faktördür. Buğday bitkisi, protein sentezinde gereksinim duyduğu elementleri havadaki $\mathrm{CO}_{2}$ ve sudan, azot ve mineralleri topraktan almaktadır. Topraktan alınabilir azot (N) miktarı protein miktarını etkilemektedir. Tane protein oranı bakımından genotipler arasında önemli farkların olduğu farklı araştırıcılar tarafından da bildirilmektedir (Budak ve ark. 1997; Atlı 1999). Çeşit özelliğinin dışında, bitkinin farklı dönemlerinde alınan yağış miktarı, yağışın türü ve aylara göre dağılımı, hava sıcaklığı, toprak özellikleri ve kültürel uygulamalar (özellikle gübreleme uygulamalarının) tane protein miktar ve kalitesini etkilemektedir (Çağlayan ve Elgün 1999). Bu sebeplerle hatların gelişme durumları (erkencilik vb.) deneme yılındaki iklim koşulları ve protein oranları birlikte incelenmesi faydalı olacaktır. Ayrıca hatların verimleri protein 
oranları incelenirken dikkate alınmalıdır. Denemelerde aynı koşullarda yetiştirilen bazı hatların verimi diğerlerinden çok yüksek olabilmekte ve protein oranı buna bağlı olarak biraz daha düşük olabilmektedir. Bazı denemelerde ise hattın gelişme dönemi çevre koşullarına bağlı olarak verimi ve protein oranı diğerlerinden yüksek olabilmektedir. Toprakta alınabilir azotun bulunması ve buğdayın bunu alabilmesi protein oranı için çok önemlidir.

Makarna kalitesinde en önemli görevi proteinler üstlenmiştir. Çeşitlerin makarna kaliteleri arasındaki farklılığı protein oranı ile protein kalitesi birlikte belirlemektedir. Kaliteli bir makarna üretimi için buğday proteininin $\% 13$ ' ten fazla olması gerekmektedir (Fortini 1988). İrmik öğütme sonucunda tanedeki protein oranı yaklaşık \%1 civarında azalmakta kepekle birlikte irmikten uzaklaşmaktadır. İrmikte proteinin \%11-13 olması istenir (Özkaya ve Özkaya 1993a).

Makarnalık buğday kalitesinde sadece protein miktarı değil proteinlerin kalitesi de önemlidir. TMO makarnalık buğday alım bareminde protein kalitesine göre gruplama bulunmamakla birlikte bazı çeşitler kaliteleri ile tanındığından sektör tarafından özellikle tercih edilerek daha yüksek fiyatlarla işlem görmektedir. Buğday proteinleri, çözünürlüklerine göre albuminler, globulinler, prolaminler (gliadin) ve gluteninler olarak sınıflandırılmaktadır (Sayaslan 2007). Gluten oluşturan proteinler gliadin ve glutenindir. Gluten oluşturmayan globulin ve albumin hem miktarca daha azdır, hem de tuzlu suda çözünebildiklerinden makarna pişirme sırasında kaybolabilmektedir (Köksel ve ark. 2000). Gluten proteinlerini oluşturan glutenin ve gliadinlerin kalite üzerine etkileri farklıdır. Glutenin oranı yüksek olan çeşitler üstün pişme kalitesine sahip olmaktadırlar. Gliadin oranı yüksek olan çeşitlerden elde edilen makarnalar ise pişirildiğinde, istenilen dirilik ve sertlik azalmaktadır (Özkaya ve Özkaya 1993).

Makarnanın pişme kalitesi tüketiciler dolayısıyla makarna üreticileri, üretici ve ıslahçı içinde önemlidir. Makarnanın pişirilmesi sırasında şişen ve jelatinize olan nişasta granüllerinin tutulabilmesi ve makarna yüzeyindeki karbonhidratlar ve proteinlerin pişme suyuna geçmemesi, proteinlerin dağılmayan bir ağ yapısı oluşturma yeteneğine bağlıdır. Protein ağının sağlamlığı protein miktarından etkilendiği gibi protein kalitesinden de etkilenmektedir. Protein kalitesi daha çok kalıtım etkisi altındadır. Ancak protein oranı yüksek olan makarnalarda polipeptid zincirleri daha fazla olduğundan proteinlerin böyle bir ağ oluşturma şansı daha yüksektir (Wasık 1978). Protein miktar ve kalitesi, makarnanın pişme özellikleri yanında makarnanın ambalajlanması ve taşınması sırasında kırılmaların önlenmesi açısından da önemlidir (Elgün ve Türker 1999).

Makarna sanayinin son yıllarda kullandığı vakumlu ve çok kısa sürede yoğurma yapabilen sistemler kullanıldığından makarnalık buğdayların protein miktar ve kalitesinin yüksek olması gerekmektedir.

Bulgur kalitesi bakımından ise Kaplan Evlice (2016) yaptığı çalışmasında iki farklı yıla ait buğday ve bu buğdaylardan laboratuvarda yaptığı bulgur örneklerinde kalite analizlerini yaparakkalite kriterleriarasındakikorelasyonları incelemiştir. Bin tane ağırlığının bulgur verimi üzerine önemli bir etkisi olduğunu belirlemiştir. Protein oranı, SDS sedimentasyon değeri, yaş ve kuru gluten miktarlarının bulgur kalitesini tahmin etmede etkili olduğunu bildirmiştir.

Makarnalık buğday ıslah çalışmalarında ıslah kademesine bağlı olarak analizler yapılarak aşağıdaki parametreler ile protein miktar ve kalitesi değerlendirilmektedir.

- Beklemeli SDS ve SDS sedimentasyon değeri

- Glutopik parametreleri

- Gluten ve glutograf parametreleri

- Miksograf parametreleri

- Alveograf parametreleri

SDS (sodyum dodesil sülfat) sedimentasyon analizi, protein miktar ve kalitesinin bir göstergesi olup, yaygın bir şekilde kullanılmaktadır. SDS sedimentasyon analizinde un tanecikleri büyüdükçe SDS sedimantasyon değeri azalmaktadır (Williams ve ark. 1988 ). Protein miktarı yetiştirme koşullarından etkilenen bir kalite kriteri olmasına rağmen, protein kalitesi daha çok genetik etkiye bağlıdır. SDS sedimentasyon değeri ile makarna pişme kalitesi ile arasında yüksek bir korelasyon değeri vardır (Dexter ve ark. 1981). Beklemeli SDS sedimentasyon analizi hem süne zararı hem de protein kalitesi hakkında bilgi veren bir analizdir. Standart ve beklemeli SDS-sedimentasyon değerleri arasındaki fark, süne zararından dolayı gluten kalitesinde oluşan bozulmanın tespit edilmesinde yaygın olarak kullanılmaktadır (Köksel ve ark. 2000). Süne emgi zararı yoksa bir hat veya çeşidin 
beklemeli SDS sedimentasyon değerinin SDS sedimentasyon değerinden daha yüksek bir değer olması beklenilir. Beklemeli SDS sedimentasyon değeri SDS sedimentasyon değerinden ne kadar yüksekse protein kalitesi de o kadar iyi demektir.

SDS sedimentasyon ve beklemeli SDS sedimentasyon analizleri makarnanın pişme kalitesi .hakkında bilgi verdiğinden ve az miktarda numune ile yapılabildiğinden ıslahın erken kademesinde yaygın bir şekilde kullanılmaktadır. SDS sedimentasyon kalıtım derecesini belirlemek için yapılan çalışmalarda 0.53 (Sarrafi ve ark. 1989), 0.278 (Akçura 2009), 0.53 (Sarrafi ve ark. 1989), 0.57 - 0.68 (Clarke ve ark. 1993) ve 0.744 (Sakin ve ark. 2011) olarak belirlemişlerdir.

Pehlivan ve Ünver İkincikarakaya (2016) makarnalık buğdaylarla (184 hat ve çeşit) yaptığı bir çalışmada tavlama yapılmış ve yapılmadan öğütülmüş buğdayların SDS sedimentasyon ve un renk b değerlerini karşılaştırmıştır. Deneme ortalaması tavlı ve tavlamadan öğütmede sırasıyla renk b değerinde 17,9 ve 17,1 iken, SDS sedimentasyonda 30.6 $\mathrm{ml}$ ve $39.4 \mathrm{ml}$ olarak bulunmuştur. Öğütme yöntemleri arasındaki korelasyon değerleri ise SDS sedimentasyonda $r=0,94^{* *}$ iken, renk b değerinde $r=0,92^{* *}$ olarak belirlenmiştir. Tavlama yapılarak ve yapılmadan öğütülerek elde edilen unların SDS sedimentasyon değerleri arasında farklılık -3.5-27 arasında ortalama $8.5 \mathrm{ml}$ olarak belirlenmiştir. Protein kalitesi iyi olan Eminbey çeşidinde $22.3 \mathrm{ml}$, orta protein kalitesindeki Kızıltan 91 çeşidinde ise $6.7 \mathrm{ml}$ farklılık belirlenmiştir. Tavlama ile taneye verilen rutubet, kabuğa dayanıklılık ve elastikiyet, endosperme de yumuşaklık veren bir faktördür. Tane rutubeti düşük olduğu zaman öğütme yapıldığında (tavlamadan) fazla miktarda kepek tozu oluşur, unda ise aşırı nişasta zedelenmesi meydana gelir ve uygun bir un granülasyonu sağlanamaz (Özkaya ve Özkaya 2005). Bu sebeple öğütme metotlarında belirtildiği gibi mutlaka tavlama yapılmalıdır.

SDS sedimentasyon, gluten, miksograf ve alveograf analizlerini kırmada yapmak yerine unda yapmak tekrarlanabilir sonuçlar alabilmek için gereklidir. Un elde etmek için makarnalık buğday mutlaka tavlanarak öğütülmelidir.

Brabender GlutoPik cihazı ile kısa sürede ve az miktarda numune ile gluten kalitesi ayırt edilebilmektedir. Bu cihazda un su karışımına yüksek karıştırma kuvveti uygulanarak agregasyon özellikleri ölçülmektedir. Gluten kalitesinin belirlenmesi için öncelikle gluten ayrılmakta; daha sonra gluten ağı oluşmakta ve devam eden hızlı karıştırma ile oluşan ağ parçalanmaktadır. Maksimum noktaya ulaşma için geçen zaman, pik yüksekliği ve takip eden pikteki düşüş gluten kalite değerlendirmesinde temel bilgilerdir ve oldukça kısa sure içerinde ölçülebilmektedir (Anonim 2017d). Cihaz otomatik olarak değerlendirerek elde edilen pikte gluten ağının oluştuğu ve maksimum pikteki direnci ve maksimumun 15 s öncesi ve 15 s sonrasındaki direnci vermektedir. Karaduman ve ark. (2015), GlutoPik parametrelerinin hızlı, kolay ve tekrarlanabilir bir şekilde gluten kalitesinin belirlenmesinde kullanılabileceğini bildirmişlerdir. Yaptıkları çalışma sonucunda GlutoPik parametrelerinden özellikle gluten maksimum direnci (BEM) ve gluten maksimum dirençten 15 s sonraki direnç (PM) değerleri melez bahçesindeki ebeveynler arasında ayırt edici bulmuşlardır.

Makarna sanayi kaliteli üretim yapabilmek için gluten miktarı (\%) ve gluten indeks değeri (\%) yüksek olan makarnalık buğdayı hammadde olarak talep etmektedirler. Makarnalık buğday ıslah çalışmalarında protein kalitesinin belirlenmesinde gluten indeks değeri önemli bir parametre olup yüksek olması istenir. Yapılan çalışmalarda yaş gluten miktarında 0.231 (Bilgin ve ark. 2010), gluten indeksinde 0.84 - 0.93 (Clarke ve ark. 2000) kalıtım derecesi belirlemişlerdir. Cubadda ve ark. (1992) yaptıkları çalışma sonucunda gluten indeks değerinin \%65-80 arasında iyi \%80 üzerini çok iyi olarak tanımlamışlardır. Hatların kaliteleri değerlendirilirken gluten miktarı ve özellikle gluten indeks değeri kalite standart çeşidine yakın ve daha yüksek değerlere sahip hatlar seçilerek bir üst ıslah kademelerine alınmalıdır.

Glutograf cihazı ile.glutograf parametreleri belirlenmektedir ve Glutograf analizinde gerilme (stretch) glutenin uzamasının, gevşeme (relaxation) ise elastikiyetinin ölçüsüdür. Gluten kuvveti ve kalitesi arttıkça gerilme (stretch (s)) değerinde artış gevşeme (relaxation $(B U))$ ve gerilme (stretch $(B U))$ değerinde ise azalma beklenmektedir (Anonymous 2005). Elde edilen stretch (sn) değeri kullanılarak hesaplanan gluten kalite değerinin makarnalık buğday ıslah hatlarında 5'den daha yüksek olması istenmektedir. Tarla Bitkileri Merkez Araştırma Enstitüsü Kalite ve Değerlendirme Bölümü'nde bu konu ile ilgili birçok çalışma yapılmıştır. Aynı yıla ait altı farklı lokasyondan 
gelen makarnalık buğday materyali kullanılarak yapılan bir çalışmada, gluten kalite değerleri Çeşit 1252'de 5.2- 6.0, Kızıltan 91'de 3.3- 4.7, Kunduru 1149'da 3.5- 4.4 ve 2009 yılında tescil edilen Eminbey çeşidinde 7.1-8.0 arasında bulunmuştur. Yapılan çalışmalarda gluten kalite değerinin çeşidin genetik yapısına bağlı olduğu, çevre koşullarından fazla etkilenmediği görülmüştür (Anonim 2007). İleri kademe ıslah hatlarının gluten kalite değerinin belirlenmesi sanayinin istediği yönde protein kalitesi yüksek çeşit geliştirmek için önemlidir.

Özderen (2009) yaptığı çalışmada sağlam ve süne zararı görmüş makarnalık buğdaylarda süneli örneklerin glutograf "stretch (s)" değeri ile yaş ve kuru gluten değerleri sağlam örneklere göre azaldığını relaxation (BU) değerinin sağlam örneklere göre arttığını belirlemiştir. Glutograf parametreleri gluten kalitesindeki bozulmayı göstermektedir.

Miksograf durum buğdayı kalitesinin belirlenmesinde kullanılmaktadır. Bir çalışmada 6 farklı lokasyonda yetiştirilen 8 farklı durum buğdayı çeşidi kullanılmıştır. Yüksek miksogram değerlerine sahip olan hatların pişmiş makarna sertlik değerlerinin de yüksek olduğu saptanmıştır (Dick ve Quick 1983). Şahin ve ark. (2015) makarnalık hat ve çeşitleri ile yaptıkları bir çalışmada SDS sedimentasyon ile miksogram parametreleri arasında pozitif ve önemli korelasyonlar bulmuşlardır. Miksograf grafiğinden elde edilen parametreler (Miksogram gelişme süresi (dk) (MMT), Miksogram pik yüksekliği (\%) (MPH), Miksogram sağ pik eğimi (dk/\%) (MRS), Miksogram pik genişliği (\%) (MPW), Miksogram bant alanı (Nm) (MBE), Miksogram toplam alan (Nm) (MTE)) ile protein kalitesi değerlendirilmiş iki hat ve Eminbey çeşidinin yüksek kaliteye sahip olduğu belirlemişlerdir. Braaten ve ark. (1962) yaptıkları çalışmada miksogram için 0.56-0.64 kalıtım derecesi belirlemişlerdir. Makarnalık buğday ıslah programlarında son ürün kalitesinin tahmininde Miksograf analizinin çok kullanışlı ve pratik bir test olduğunu bildirmişlerdir. Miksograf analizi süresinin kısa olması, az miktarda örnekle çalışılabilmesi (35 $\mathrm{g}$ un) ve miksograf kurvesinin yorumu ile kalitesi yüksek genotiplerin belirlenebilmesi Alveograf analizine göre bu analizi ıslah programları erken generasyonda da daha avantajı kılmaktadır.

Protein miktarı ve gluten kalitesinin (alveograf W değeri) makarna pişme kalitesini etkileyen en önemli parametreler olduğu öne sürülmüştür. Protein miktarının çevreden önemli düzeyde etkilenmesine karşın protein kalitesinin (alveograf W değeri) genotipten daha çok etkilendiği bildirilmiştir (D’Egidio ve ark.1990, Mariani ve ark. 1995). Alveograf parametreleri makarna kalitesin belirlenmesinde yaygın bir şeklide kullanılmaktadır. Özellikle kuru gluten miktarı, alveograf enerji değeri (W) ve P/L değerleri ile makarna pişme kalitesi tahmin edilebilmektedir. Kaliteli makarnalık buğdayın alveograf enerji değerinin $250 \mathrm{~W} 10^{-4}$ joule'ün üzerinde ve $P / L$ oranının ise $0.5-1.5$ olması gerekmektedir (Landi 1995).

Alveograf testi; sabit şartlar altında un, tuz ve su ile hazırlanan hamur parçalarının bir süre bekletilip hava ile şişirilmesi ve böylece hamurun uzamaya (şişmeye) karşı gösterdiği direncin ölçüldüğü; direncin bir kurve halinde (alveogram) kaydedilmesinden sonra elde edilen kurvenin alanı (enerji değeri W $10^{-4}$ joule), yüksekliği ( $P \mathrm{~mm})$, taban uzunluğu ( $\mathrm{L} \mathrm{mm}$ ) ve $\mathrm{G}$ (kabarma indeksi $\mathrm{cm}^{3}$ ) hamuru şişirmek için kullanılan hava miktarının kare köküdür (Elgün ve ark. 2001). Hamurun uzama kabiliyeti ve deformasyona karşı direnci hakkında fikir veren bir kriterde $P / G$ değeridir. $B u$ analiz için kullanılan un miktarının fazla olması sebebiyle ancak ileri ıslah kademelerinde uygulanabilmektedir. Alveograf enerji değeri kalite standartı çeşitten daha yüksek olan hatlar protein miktar ve kalitesi yönüyle tescil için düşünülebileceğini göstermektedir.

Kanada'da yapılan bir çalışmada (10 çeşitle 2 lokasyonda, 3 yıl boyunca) azotlu gübrelemenin protein miktarı ve kalitesi üzerine etkileri belirlenmeye çalışılmıştır. Deneme sonucunda azotlu gübrelemenin bütün çevrelerde protein oranını artırmıştır. Tüm gübreleme seviyelerinde SDS, gluten indeksi, alveograf, mixograf gibi değerler çeşitlere göre farklılık göstermiştir. Bütün uygulamalarda artırılan azot seviyeleri karşısında GI (gluten indeksi) değerleri diğer özelliklere göre daha stabil bulunduğu için, bu parametrenin gluten mukavemetini tahmin etme açısından iyi bir test olduğuna dikkat çekilmiştir (Ames ve ark. 2003).

El-Haremein ve ark. (1996), Suriye'de üç farklı lokasyonda (iyi yağış alan veya sulanan, orta yağışlı ve yarı kurak) 50 makarnalık buğday çeşidi ile 5 yıl süren bir çalışma yapmışlardır. Çalışma sonucunda çevreden en fazla etkilenen karakterin protein oranı olduğunu ve kurak yıllarda protein oranının arttığını, SDS değerinin ise protein oranına göre daha az etkilendiğini, genelde düşük yağışlı yıllarda SDS 
değerinin ve sarı renk pigmentinin yükseldiğini, protein oranı ve camsılığın, genotipten daha çok çevreden etkilendiğini açıklamışlardır.

Makarnanın pişme kalitesinde etkili olan spesifik gliadin proteinleri $\mathrm{Y}$-gliadin 42 ve Y-gliadin 45 proteinleridir (Troccoli, 2000, Koyuncu 2009, Yüksel 2009) Y-Gliadin 45 proteini makarnada optimum gluten kuvveti ve yüksek pişme kalitesinin, y-gliadin 42 proteini ise zayıf gluten ve düşük pişme kalitesinin bir göstergesi olarak kabul edilmektedir. Son yıllarda yapılan çalışmalar, makarnalık buğdayların gluten kuvvetleri ve makarna pişme kalitelerinde esas belirleyici proteinlerin Y-gliadin 42 ve Y-gliadin 45 proteinleriyle genetik olarak ilişkili olan sırasıyla düşük molekül ağırlıklı LMW-1 ve LMW-2 glutenin proteinleri olduğunu göstermiştir.

Islah programlarında özellikle melez bahçesinde ve erken kademelerde analiz yapılabilecek materyal az olduğundan elektroforez tekniği kullanılarak gliadin elektrogramlarına göre seleksiyon yapılması ve Y-gliadin 45 (LMW-2 glutenin) proteinlerini de içeren hatların seçilmesi protein kalitesi yüksek çeşitlerin geliştirilebilmesine olanak sağlar (Atlı ve ark. 2010).

\section{Renk Değeri (b Sarılık)}

Makarna, bulgur ve irmik için tanedeki sarı renk pigmenti miktarı oldukça önemlidir Tüketici tarafından parlak sarı renkte olan makarna tercih edildiği için, makarnalık buğdayda irmik b sarılık değeri yüksek çeşitler makarna sanayi tarafından özellikle istenmektedir (Pehlivan ve ark. 2008). Makarnalık buğdaylarda sarı renk pigmentleri diğer tahıllardan daha fazla bulunmaktadır. Taneye sarı rengi veren karotenoid grubu pigment miktarı, buğdayın türüne, çeşidine ve yetiştirilme koşullarına göre değişmektedir. Buğdayda bulunan sarı renk maddesi, ksantofil, lütein ve taraksantin pigmentleri tarafından oluşturulmaktadır. Bu renk maddesi karoten olarak ifade edilmekte ve suda doymuş n-bütil alkolde ekstrakte edilen sarı renk maddesini tanımlamaktadır. İrmikteki pigment miktarı 4-8 ppm arasında değişmektedir (Özkaya ve Özkaya 1993b). Yapılan başka bir çalışmada ise makarnalık buğdaylara ait sarı pigment miktarı 3.0 ppm ile 6.9 ppm arasında değişmiş ve bu çeşitler içerdikleri sarı pigment miktarına göre orta kaliteli (3.0-5.0 ppm) ve iyi kaliteli (>5.0 ppm) olarak ikiye ayrılmıştır (Mohammed ve ark. 2012).

Makarnalık buğdayda pigment miktarı tayininde suda doymuş bütanol ekstarksiyon metodu veya HPLC ve NIR tekniği gibi bazı yöntemler kullanılmaktadır (Reimer 2008). Kimyasal kullanımını gerektirmeyen, hızı ve pratik bir yöntem olan, Commission Internationale de l'Eclairage (CIE 1976) tarafından geliştirilmiş, CIE L, a, b (CIELAB) veya Hunter Lab ölçüm yöntemi yaygın olarak kullanılmaktadır. Islah çalışmalarında un veya irmik renk analizleri genelde spektrofotometre ile Hunter kolorimetre değerlerine göre belirlenmektedir. $L$ değeri örneğin parlaklığı ile ilgili olup 100 olduğunda beyaz, 0 olduğunda siyah, a değeri kırmızı-yeşil, b değeri ise sarımavi rengin göstergesidir. +a kırmızılık değeri ve +b sarılık değeri olarak ifade edilmektedir (Kaplan ve Özkaya 2011) Sarı pigment miktarı ile spektrofotometre ile belirlenen değerlerin karşılaştırıldığı iki farklı lokasyonda yapılan bir çalışmada b sarılık değeri ile toplam sarı pigment miktarı arasında pozitif yüksek

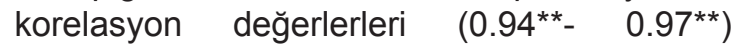
bulunmuştur (Reimer 2008).

Makarnalık buğdayda $L$ aydınlık ve b sarı renk önemlidir. Manthey (2001) yapmış olduğu çalışma sonucunda $L$ değerine genotip etkisinin \%12.6, çevre etkisinin \%67.9 ve diğer faktörlerin etkisinin \%19.5, b sarılık değerine ise genotip etkisinin \%86.6, çevre etkisinin \%8.5 ve diğer faktörlerin etkisinin \%4.9 olduğunu bildirmiştir. Ayrıca $L$ değerine çevrenin etkisi üstünlük gösterirken, b değerine genotipin etkisinin üstünlük gösterdiğini, irmik renginin yüksek derecede kalıtsal bir özellik olup eklemeli gen etkisi ile kontrol edildiğini belirtmiştir. Yapılan bir başka çalışmada eklemeli gen etkisinde olan pigment miktarına genotip etkisinin \%88 ile \%95 arasında değiştiği belirlenmiştir (Clarke ve ark. 2006). İrmik rengi lokasyon ve yıllara göre değişmekle birlikte daha çok genetik kalıtımın etkisindedir. Pigment miktarı (irmik rengi) kalıtım derecesini belirlemek için yapılan bazı çalışmalarda; Bilgin ve ark. (2010) 0.894, Mohammed ve ark. (2012), 0.843, Clarke ve ark. (2000) 0.29-0.53 arasında ve Akçura (2009) 0.50 olduğunu bildirmişlerdir. Bu nedenle b sarılık değeri ıslah çalışmalarında erken kademede seleksiyon kriteri olarak kullanılmaktadır.

Pehlivan ve ark. (2008) tarafından yapılan bir çalışmada makarnalık buğdaylarda tanenin ve irmiğin renk değerleri arasındaki ilişki incelenmiştir. Elde edilen verilere göre; tane ve irmik L, a, b değerleri arasındaki korelasyon oldukça düşük bulunmuştur. Hunter Lab 
kolorimetresine göre sarılığı ifade eden b değerleri bakımından tane ile irmik arasında $0.29^{* *}$ korelasyon değeri bulunmuştur. Ayrıca çalışmada yer alan 371adet makarnalık buğday hattında benzer tane b sarılık değerine sahip hatların irmik b sarılık değerlerinin çok farklı olduğu görülmüştür. Örneğin tane b değeri 18.1 olan iki hattın irmik b değerleri 16.75 ve 23.59 olarak belirlenmiştir. Makarnalık buğday tanesinin rengine gerek gözle gerekse spektrofotometrik olarak bakılarak irmik renginin tahmin edilmesinin çok doğru olmayacağı sonucuna varılmıştır. İrmik rengi, buğday tanesinin irmiğe öğütülmesi ile belirlenmelidir. (Pehlivan ve ark. 2008). Çünkü buğdaya sarı renk veren karotenoid pigmentleri tane içerisindeki muhtelif kısımlarda farklı oranlarda bulunmaktadır (Borelli ve ark.1999).

Yüksek orandaki sarı pigmentler makarna ve bulgurun renginin parlak sarı olmasını sağlamaktadır. Ancak yüksek düzeyde lipoksigenaz enzimi (LOX-2 ve LOX-3 isoenzimleri) olduğunda makarna yapma sırasında irmiğin sarı pigmentleri oksidasyona uğramakta ve arzu edilen renkte makarna elde edilemeyebilmektedir Makarnalık buğday ıslahında, LOX aktivitesi tayininin rutin olarak yapılması çok yaygın değildir (Atlı ve ark. 2010).

Makarnanın pişme kalitesi en önemli özelliklerden biridir. Islah çalışmalarında makarna yapımı ve pişirme özelliklerinin değerlendirilmesi laboratuvar olanaklarına göre yapılabilmektedir. Suya geçen madde miktarı (pişme kaybı), hacim artışı, su absorpsiyonu, toplam organik madde (TOM) tayini analizleri ve kuru ve pişmiş makarnada tekstür analizleri de yapılmaktadır. Protein miktar ve kalitesi çok iyi olan hat ve çeşitlerin pişme özellikleri de iyi olmaktadır (Atlı ve ark.2010).

Makarnalık buğday ıslah çalışmalarında kalite analizlerinde pek çok yöntem kullanılmaktadır Çizelge 7. İncelendiğinde

Çizelge 7. Makarnalık buğday kalite analizlerinde kullanılan yöntemler Table 7. Methods used in quality analysis of durum wheat

\begin{tabular}{|c|c|c|c|}
\hline Analiz Adı & Metot & Analiz Adı & Metot \\
\hline Rutubet Miktarı & & Rutubet Miktarı & $\begin{array}{l}\text { AACCI Standart Metot No: } \\
\text { 44-15A, TS } 1135\end{array}$ \\
\hline $\begin{array}{l}\text { Bin Tane Ağırlığı } \\
\text { Tane Boyutu }\end{array}$ & $\begin{array}{c}\text { SKCS (Single Kernel Charac- } \\
\text { terization System) AACC Metod } \\
\text { No:55-31 }\end{array}$ & $\begin{array}{l}\text { Bin Tane Ağırlığı } \\
\text { SDS sedimentasyon } \\
\text { analizi }\end{array}$ & $\begin{array}{l}\text { Köksel vd. (2000) } \\
\text { Williams vd. (1988) (modifiye), } \\
\text { ICC Standart No:151, AACCI } \\
\text { Standart Metot No: } 56-70\end{array}$ \\
\hline Sertlik Değeri & & $\begin{array}{l}\text { Beklemeli SDS sedi- } \\
\text { mentasyon analizi }\end{array}$ & Williams vd. (1988) (modifiye) \\
\hline Hektolitre Ağırlığı & $\begin{array}{l}\text { TS ISO 7971-3, Vasiljevic ve } \\
\text { Banasik (1980) }\end{array}$ & Camsı Tane Oranı & $\begin{array}{l}\text { ICC Standart No:129, Özkaya } \\
\text { ve Özkaya (2005), TS } 2974\end{array}$ \\
\hline $\begin{array}{l}\text { Renk Değeri (L, a, b) } \\
\text { (un, irmik ve makarna) }\end{array}$ & $\begin{array}{l}\text { Kolorimetrik olarak (ASTM E } \\
\text { 1164), }\end{array}$ & Beta Karoten Miktarı & $\begin{array}{l}\text { AACCI Standart Metot No: } \\
14-50\end{array}$ \\
\hline Protein Miktarı (Dumas) & $\begin{array}{l}\text { AACCI Standart Metot No::46- } \\
30\end{array}$ & $\begin{array}{l}\text { Protein Miktarı (NIR- } \\
\text { NIT) }\end{array}$ & $\begin{array}{l}\text { AACCI Standart Metot No: } \\
39-10\end{array}$ \\
\hline Un Öğütme & $\begin{array}{l}\text { AACCI Standart Metot No:26-50, } \\
26-21 \text { ve } 26-31\end{array}$ & İrmik Öğütme & AACC Metod No:26-41 \\
\hline $\begin{array}{l}\text { Yaş Gluten ve Gluten } \\
\text { İndeks }\end{array}$ & $\begin{array}{l}\text { AACCI Standart Metot No: 38- } \\
\text { 12A ICC Standart No:158 }\end{array}$ & Kuru Gluten & $\begin{array}{l}\text { AACCI Standart Metot No: } \\
\text { 38-12A, Özkaya ve Özkaya, } \\
2005\end{array}$ \\
\hline Glutograf Parametreleri & Anonymous, 2005 & Glutopik analizi & Melnyk vd. (2011) \\
\hline Miksograf analizi & AACCI Standart Metot No: $54-40$ & Alveograf Özellikleri & $\begin{array}{l}\text { AACCI Standart Metot No:54- } \\
50\end{array}$ \\
\hline Makarna Yapımı & D'Egidio et al. 1982 & $\begin{array}{l}\text { Makarna pişirilmesi ve } \\
\text { duyusal değerlendirme }\end{array}$ & D’Egidio et al., 1982 \\
\hline $\begin{array}{l}\text { Toplam Organik Madde } \\
\text { Tayini }\end{array}$ & $\begin{array}{l}\text { D’Egidio et al., 1982, Köksel vd., } \\
\text { 2000' }\end{array}$ & $\begin{array}{l}\text { Suya Geçen Madde } \\
\text { Miktarı (pişme kaybı) }\end{array}$ & TS 1620, Köksel vd., 2000 \\
\hline Hacim Artışı Tayini & Köksel vd., 2000 & Su absorpsiyonu & Köksel vd., 2000 \\
\hline $\begin{array}{l}\text { Makarnada Tekstür } \\
\text { Analizi }\end{array}$ & AACC Metod No: $16-50$ & $\begin{array}{l}\text { Makarnada Ekmeklik } \\
\text { Buğday Tespiti }\end{array}$ & $\begin{array}{l}\text { Biopharm Durotest S Kiti } \\
\text { Metodu }\end{array}$ \\
\hline
\end{tabular}


büyük çoğunluğu uluslararası standart metotlar olduğu bir kısmının ise bazı araştırmacılar tarafından modifiye edilmiş metotlardır.

Makarnalık buğday ıslah kademelerinden gelen numune miktarları farklı olduğundan kalite değerlendirilmesi için yapılacak analizler ıslah kademesine göre değişmektedir. Tarla Bitkileri Merkez Araştırma Enstitüsü makarnalık buğday ıslah programında kalite analizleri ön verim denemesinde $\left(F_{6}\right.$ veya $\left.F_{7}\right)$ başlamaktadır. Bu aşamadan önce taneye zarar vermeden near infrared transmittance (NIT) cihazları ile protein oranını ve bin tane ağırlığının elle sayılması analizleri yapılabilir. Ayrıca ıslah materyalinde melez bahçesi, gözlem bahçesi gibi aşamalarda bu analizlerin yanısıra elektroforez (gliadin ve gluteninde) yapılabilmektedir. Islah çalışmalarında makarna kalitesini olumlu etkileyen proteinlerden en önemlileri olan Gli-B1 lokusunda bulunan y-gliadin 45 ve bu lokusla çok sıkı bağlantılı olan Glu-B3 lokusu tarafından kodlanan LMW-2 glutenine sahip hatların seçilmesi kaliteli çeşit geliştirebilmek için önemlidir.

Bu denemede kalite analizi için kullanılacak numune miktarı az olduğundan aşağıdaki analizlerle kalite belirlenir.

- Bin tane ağırlığı (g)

- Camsı tane oranı (\%)

- Protein oranı (\%)

- SDS sedimentasyon değeri (ml) (un)

- Un rengi $(\mathrm{L}, \mathrm{a}, \mathrm{b})$

- Elektroforez çalışmaları ( $ү$-gliadin 45 )

Erken kademe materyalinde analiz için ayrılabilecek numune miktarı az fakat numune sayısı çok (500-800 adet) olduğundan ve kısa sürede analizlerin sonuçlandırılarak tarlaya ekim için hatların seçilmesi gereklidir. Bu kademede analizler unda yapılabilmektedir. Tarla Bitkileri Merkez Araştırma Enstitüsü makarnalık buğday ıslah programında yapılan bir çalışma sonucunda Un SDS sedimentasyon değeri ile irmik $(0.8 \mathrm{~mm}$ elek açıklığında) SDS sedimentasyon değeri arasında 0.93 korelasyon, un b sarılık değeri ile irmik b sarılık değeri arasında 0.94 korelasyon değeri bulunmuştur. Kalite sonuçları yıl ve çevreye göre değiştiğinden minimum kalite değerleri göz önüne alınmakla birlikte değerlendirme her zaman ön verim denemesinde yer alan kalite standart çeşidinin sonuçları ile karşılaştırılarak yapııır. Erken kademe kalite değerlendirilmesinde SDS sedimentasyon değerinin yüksek olması istenir bu değer protein miktar ve kalitesini göstermektedir. Analizin yapıldığı materyal analiz sonucunu etkilemektedir. Kırma, öğütülmüş irmikte (0.8 $\mathrm{mm}$ elek açıkığı) veya unda yapılmaktadır. Tarla Bitkileri Merkez Araştırma Enstitüsü Kalite Değerlendirme ve Gıda bölümünde yapılan ön denemelerden elde edilen bulgulara göre; irmikte parçacık (partikül) iriliği homojen olmadığı için tekrarlanabilir sonuçlar almanın zor olduğu, ayrıca kaliteli iri parçacık içeren irmiklerin düşük kaliteli unsu irmiklerden daha düşük sonuçlar verebildiği bu sebeple analiz irmikte yapılacaksa mutlaka ikinci bir öğütme $(0.8 \mathrm{~mm}$ elek açıklığı) yapılması gerektiği ve unda tekrarlanabilir sonuçlar alındığı görülmüştür. Hasat sonrasında erken kademe materyalinin analizleri hemen yapılmalı kalite bakımından değerlendirilmelidir. Islahçı ekim öncesinde bu kalite değerlendirmesini de dikkate alarak seleksiyon yapmakta ve seçtiği hatları bir ileri ıslah kademesine aktarmaktadır.

İleri kademe verim denemelerinde 2-3 farklı lokasyonda yetiştirilen kalite analizlerinin sonuçları değerlendirilerek standart hatlardan iyi özellik gösteren hatlar bölge verim denemelerine önerilir. İleri kademe verim denemelerinde ve bölge verim denemelerinde farklı lokasyonlarda (lokasyon sayısının fazla olması istenir) yetiştirilen hatlar ile birlikte yetiştirilen standart çeşitlerde aşağıda belirtilen kalite analizleri yapılır.

- Hektolitre ağırlığı (kg/hl)

- 1000 tane ağırığı (g)

- Camsı tane oranı (\%)

- Protein oranı (\%)

- SDS sedimentasyon değeri (ml)

- İrmik verimi (\%)

- İrmik rengi (L, a, b)

- Yaş ve kuru gluten miktarı (\%)

- Gluten İndeksi (\%)

- Glutograf parametreleri

- Miksograf parametreleri

Ayrıca laboratuvarda gerekli cihazlar varsa makarna yapımı ve makarna kalite analizleri; yapışkanlık, sertlik, kümeleşme, toplam organik madde (TOM) ve tekstür analizleri yapılarak kalite değerlendirilir. 
Kalite sonuçları farklı istatistik analizleri ile değerlendirilmektedir. Varyans analizi sonucuna göre konunun önemli çıkması durumuna bağlı olarak önemlilik testlerinde farklı grupların belirlenmesinde farklı istatistik paket programları kullanılmaktadır. Değerlendirmelerde her zaman denemelerdeki kalite standartı olan çeşidin değerlerinden daha yüksek veya yakın olan hatlar seçilmelidir.

Hatların kalite analiz sonuçlarının standart sapmaları hesaplanarak bir değerlendirme yapılabilir. Hatların kalite ve standart sapma değerleri, standart çeşit ve hatlar ile birlikte yorumlanmalıdır. Ayrıca kalite özellikleri
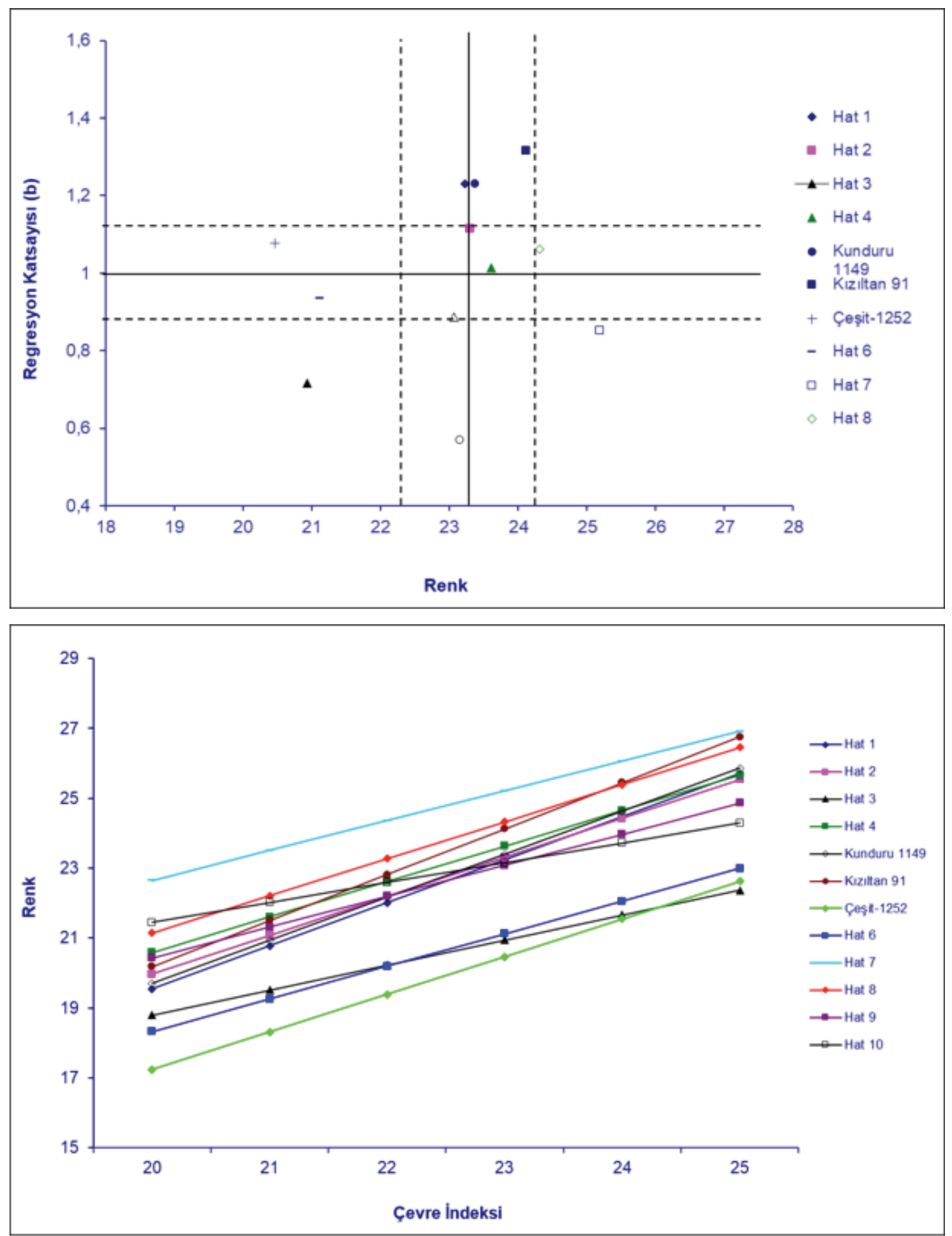

Şekil 4. İrmik rengi analizi stabilite grafiği (2007 Bölge Verim Denemesi )

Figure 4. Stability graphic of semolina colour analysis (Region yield trial 2007) 
MBVD Un rengi b değeri Scatter plot (Total - 94.15\%)

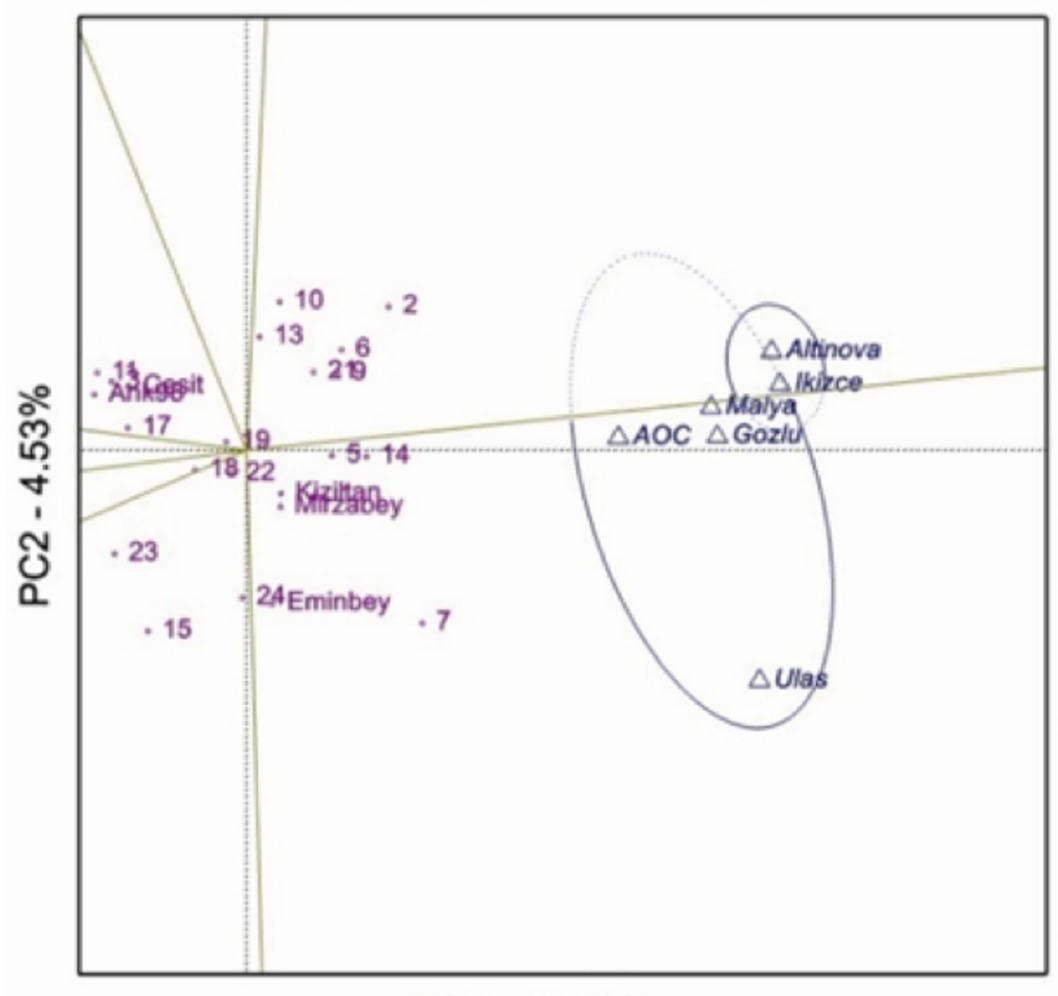

PC1 - $89.62 \%$

MBVD SDS sedimentasyon Scatter plot (Total - 92.78\%)

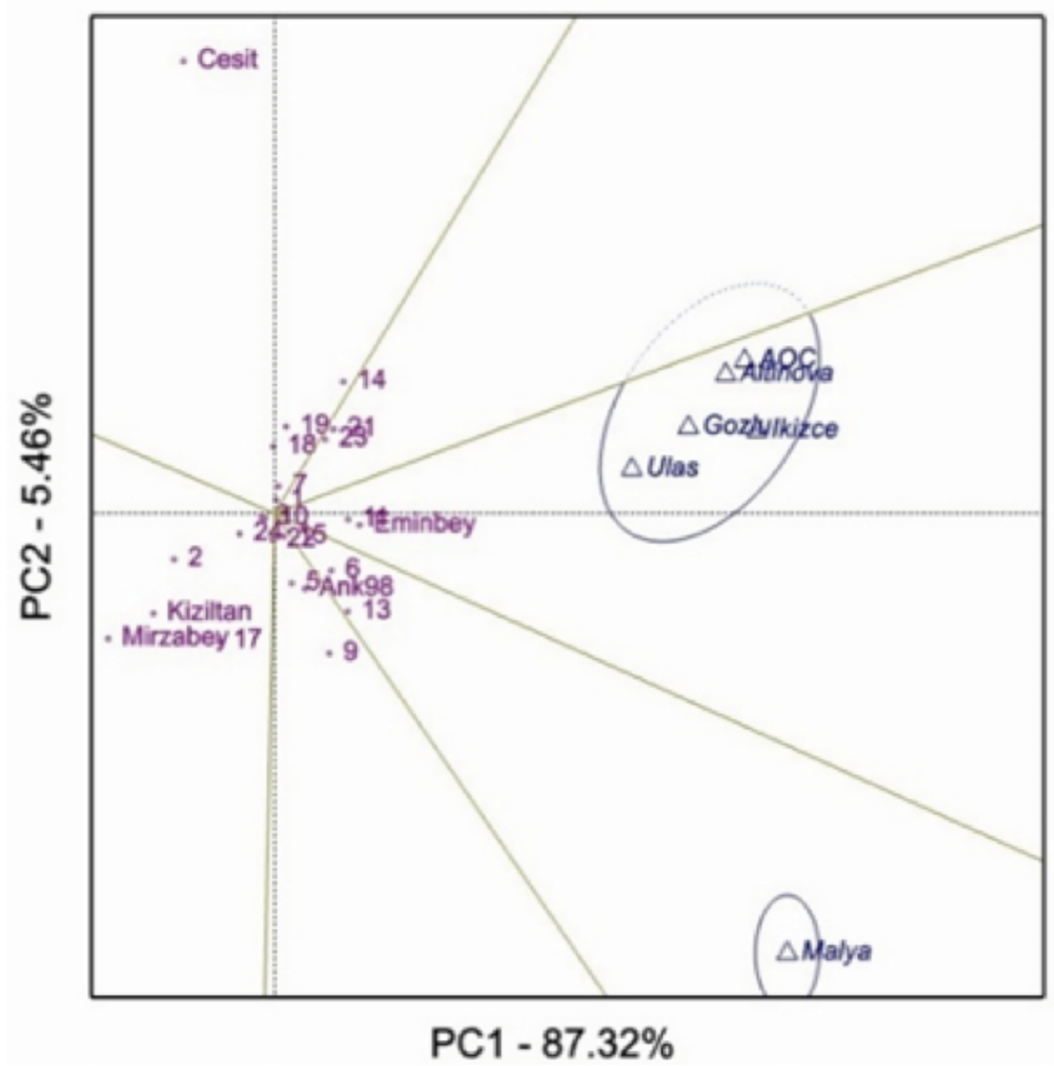

Şekil 5.Bazı önemli kalite parametrelerinin Biplot grafikleri (2015 TARM bölge verim denemesi) Figure 5. Biplot graphs of some important quality parameters (Region yield trial of TARM 2015) 
değişik çevre koşullarındaki değişiminin tespit edilerek istenen kalite özellikleri bakımından stabil olan hatlar çeşit adayı olarak değerlendirilebilir. TTSMM Teknik Talimatlar Serin İklim Tahılları Buğday talimatında çok yıllık verilerin uygunluğuna (her yıl en az 3 lokasyon) ve varyans analiz sonuçlarına göre stabilite analizi yapıldığı belirtilmektedir (Anonim 2017a). Stabilite analizleri Genotip Çevre interaksiyonunun istatiksel olarak önemli olduğu tüm veri setlerinde uygulanabilir. Bu veri setleri (genotip x yıl, genotip x lokasyon, genotip x yıl x lokasyon) verilerini içerebilir. Kalite değerleri yıl ve yetiştirme koşullarına göre değiştiğinde tescil başvurusu öncesinde İleri ıslah kademelerinden gelen hatların farklı lokasyonlardaki (en az 6) önemli kalite kriterleri yönüyle istatistiki metotlar kullanılarak stabilite analizi ile değerlendirme yapılması faydalı olacaktır. Hazırlanan stabilite grafikleri kalitenin yorumlanmasında kullanılabilir. Örneğin Şekil 4'te bir Bölge Verim Denemesinin irmik rengi stabilite grafikleri görülmektedir. Grafikler incelendiğinde Hat 7 ve Hat 8'in en iyi irmik rengi standartı Kızıltan 91 çeşidinden daha iyi değerler verdiği ve stabil olduğu görülmektedir.

Kalitenin değerlendirilmesinde GGE Biplot metodu kullanılabilmektedir. İstatistiki programlarla hazırlanabilen bu GGE biplot yöntemi iki yönlü verilerin olduğu tüm veri setinde kullanılabilir. Genotip ve genotip x çevre interaksiyonunun olduğu karakterlerde GGE biplot kullanımı son yıllarda artmıştır (Yan ve ark. 2000). GGE biplot metodu, bitki ıslahçıları ve agronomistlerinin beklentilerini karşılamaktadır. Verim denemelerinden sonra bir üst ıslah kademesi olan ileri kademe verim denemelerinin (IKMVD) lokasyon sayısı stabilite analizi için yeterli olmayıp bu metotla değerlendirilebilir. Ayrıca bölge verim denemeleri, ortak bölge verim denemeleri, tescil denemeleri ve özel sektör tohumluk üretici kuruluşlarının denemeleri birden fazla yılda veya pek çok lokasyonda yapılmaktadır. Biplot metodu ile hazırlanan grafikler ile lokasyonların, yılların hepsi bir kalite karakteri yönüyle değerlendirilebilmektedir. Biplot grafikleri ile aynı zamanda incelenen kalite parametresi yönüyle hatların ve standart çeşitlerin stabil olup olmadığı, hangi lokasyonların benzer kalite değerleri verdiği ve hangi hattın hangi lokasyonda iyi değer verdiği de görülebilir.

Örnek olması amacıyla Şekil 5'teki (Anonim 2015) Biplot grafikleri incelendiğinde, en uzun vektöre sahip olan lokasyonların genotiplerin en iyi değerlendirildiği lokasyonlar olduğu söylenebilinir. Her iki grafikte en uzun vektör uzunluğuna sahip olan lokasyon Malya Lokasyonudur. SDS sedimentasyon değerinde Malya lokasyonunun farklı özellik gösterdiği ve denemelerde mutlaka bulunması gerektiği söylenebilir. İrmik renginde ise Altınova ve İkizce aynı diğerleri ayrı büyük çevrede yer almıştır. Gözlü lokasyonunun bu deneme yılında kalite değerlendirmesine katkısının az olduğunu söylenebiliz. Lokasyonlar aynı büyük (mega) çevre içinde o kalite parametresi yönüyle benzer özellik göstermiş demektir. Yıllar da göz önüne alınarak denemelerde benzer özellik gösteren ve merkez noktaya uzaklığı değerlendirilerek lokasyonların azaltılması yerlerine yeni lokasyonlar eklenmesi hatların kalite özelliklerinin stabillik durumunun belirlenmesinde daha yararlı olacaktır.

GGE biplot grafiğindeki (Şekil 5.) parametrelerde yüksek değerler daha iyi kaliteyi belirttiğinden $Y$ ekseninden sağ tarafta bulunan hatların standart çeşitlere göre konumuna göre yorum yapılabilir. Hattın $X$ eksenine yakın olması ise o parametrede stabil özellik gösterdiğini ifade etmektedir. Örneğin SDS sedimentasyon biplot grafiğinde Eminbey çeşidinin en iyi ve stabil olduğunu 11 numaralı hattın ise en yakın hat olduğu görülmektedir. b sarılık un rengi biplot grafiğinde ise 7,2,6,14 ve 5 numaralı hatların denemedeki en iyi renk standartı olan Kızıltan 91 çeşidinden daha iyi değer gösterdiği görülmektedir fakat 5 ve 14 numaralı hatları iyi ve stabil olduğu görülmektedir. Genel değerlendirildiğinde 14 numaralı hat çeşit adayı olabilir şeklinde yorumlanabilir. Önemli kalite parametrelerinin hepsi için Biplot grafikleri hazırlanarak bu şekilde değerlendirilmeler yapılabilir.

\section{Sonuç}

Ülkemiz makarnalık buğdayın gen merkezidir ve ekolojik açıdan kaliteli makarnalık buğday yetiştirilmesine uygundur. Makarnalık buğdaylarda kalite, çeşidin genetik yapısı, yetiştirildiği yıldaki ekolojik şartlar, yetiştirme tekniği ve bilhassa kullanılan azotlu gübre miktarı ile yakından ilişkilidir $\mathrm{Bu}$ nedenle yetiştirilen bölgeye uyumlu kaliteli çeşitlerin sertifikalı tohumlukları kullanılarak uygun yetiştirme tekniklerine göre üretilmesi, kaliteli ve standart ürün için önemlidir.

TMO ve Lisanslı depoculuk makarnalık buğday sınıflandırma sisteminde fiziksel 
özellikler ve protein oranı dikkate alınmakta henüz çeşitlerin irmik renginin ve protein kalitesinin yüksek olması gruplamada bir etkisi bulunmamaktadır. Sınıflamanın bu kriterleri de göz önüne alınarak düzenlenmesi kaliteli üretimi teşvik edecektir.

Makarnalık buğday ıslah çalışmaları ile daha kaliteli, yüksek verimli, hastalıklara ve zararlılara dayanıklı ve yetiştirildiği çevrenin koşullarına uyumlu çeşitler geliştirilmeye çalışılmaktadır. Islah çalışmalarında kalite değerlendirmesi yapılırken ıslah kademesinden gelen numune miktarına bağlı olarak kalite analizleri yapılmaktadır. Analizlerin sonuçları farklı şekillerde değerlendirilmekle birlikte farklı yıl ve yerlerde kalite parametreleri bakımından stabil özellik gösteren ve denemelerdeki kalite standardı olan çeşidin değerlerinden daha yüksek veya aynı olan hatlar çeşit adayı olarak seçilmelidir. Makarna Makarnalık buğday ıslahında sanayinin istediği fiziksel özellikler yanında özellikle protein miktar ve kalitesi ile birlikte irmik b sarılık değeri yüksek kaliteli çeşitlerin geliştirilmesi gereklidir.

\section{Kaynaklar}

Akar T., 2017. Sözlü görüşme Akdeniz Üniversitesi Ziraat Fakültesi Tarla Bitkileri Bölümü, Antalya

Akçura M., 2009. Genetic variability and interrelationship among grain yield and some quality traits in Turkish winter durum wheat landraces. Turkish Journal of Agriculture and Forestry, 33(6): 547-556

Aktan B. ve Atlı A., 1993. Makarnalık buğdaylarda camsılık oranının kaliteye etkisi üzerinde bir araştırma, Tarla Bitkileri Merkez Araştırma Enstitüsü Dergisi, 2(3): 1-13

Ames, N. P., Clarke, J. M., Dexter, J. E., Woods, S. M., Selles, F. Selles and Marchylo, B., 2003. Effect of nitrojen fertilizer on protein quality and gluten strength parameters in durum wheat (Triticum turgidum L. var. durum) cultivars of variable gluten strength. Cereal Chem., 80(2): 203-211

Anonim, 2002. Türk Gıda Kodeksi Makarna Tebliği. Tebliğ No: 2002/20

Anonim, 2009a. Türk Gıda Kodeksi Bulgur Tebliği. Tebliğ No: 2009/24

Anonymous, 2005. Instruction Manual Glutograph-E, Brabender measurement and control systems, Brabender GmbH\&Co.KG. Kulturstr. 51-55. 47055 Duisburg. Germany

Anonim, 2007. Kuru Makarnalık Ortak Bölge Verim Denemeleri Sonuçları. Tarımsal Araştırmalar Genel Müdürlüğü 2007 Yılı Serin İklim
Tahılları Grup Değerlendirme Toplantısı, Antalya

Anonim, 2010. Türkiye Makarna Sektörü Makarna Sanayicileri Derneği Makarna Sektörü 2010 http://www.makarna.org.tr/TR/lcerikDetay. aspx?ID=29 (Erişim tarihi: 17.04.2013)

Anonim, 2015. Ülkesel Serin İklim Tahılları Kışlık Dilim Makarnalık Buğday Kalite Araştırmaları. Tarla Bitkileri Merkez Araştırma Enstitüsü Müdürlüğü, Ankara

Anonim, 2016a Toprak Mahsulleri Ofisi Genel Müdürlüğü http://www.tmo.gov.tr Upload/Document/alim/2016/2016\%20 D \% C $3 \%$ B 6 ne m i \% 20 Hububat $\% 20$ Al\%C4\%B1m\%20Baremi.pdf (Erişim tarihi: 17.04.2017)

Anonim, 2016b Toprak Mahsulleri Ofisi Genel Müdürlüğü Hububat Raporu http://www. tmo.gov.tr/Upload/Document/hububat/ hububatraporu2016.pdf (Erişim tarihi: 17.04.2017)

Anonim, 2016c. Ekonomi Bakanlığı Tarım Ürünlerine İlişkin Dahilde İşleme Rejimi Genelgesi (İhracat: 2016/1) http://www.ekonomi.gov.tr/portal/ faces/home/ihracat/mevzuat/ihrMevzuatDir? afrLoop $=1248816932628868$ \& a f $r$ W i n d o w M o d e = 0 \& frWindowld=3spvmirvh_62\#! $\% 40 \% 40 \% 3 F_{-}$ afrWindowld\%3D3spvmirvh_62\%26_ afrLoop\%3D1248816932628868\%26_a frWindow Mode\% 3 D $0 \% 26$ _adf. ctrlstate\%3D3spvmirvh_116 (Erişim tarihi: 02.05.2017)

Anonim, 2017a. http://www.tarim.gov.tr/BUGEM / TTSM/Sayfalar/Detay. aspx?Sayfald $=55$ (Erişim tarihi: 29.04.2017)

Anonim, 2017b Türkiye Makarna Sanayicileri Derneği http://www.makarna.org.tr/d/ makarna-sektoru/makarna-tuketimi/42/ (Erişim tarihi: 17.04.2017)

Anonim 2017c Tohumluk Tescil ve Sertifikasyon Müdürlüğü TTSMM 2017 Milli Çeşit Listesi http://www.tarim.gov.tr/BUGEM/TTSM/ Sayfalar/Detay.aspx?Sayfald=85 (Erişim tarihi: 05.05.2017)

Anonim, 2017d. www. Brabender.com. http:// www.brabender.com/english/food/news/n ews/datensaetze/brabenderr-glutopeakquickpeak-values-for-gluten-testing.html. (Erişim tarihi: 17.04.2017)

Atlı A., 1985. İç Anadolu'da yetiştirilen bazı ekmeklik buğday çeşitlerinin kalite özellikleri üzerine çevre ve çeşidin etkileri. Doktora Tezi, Ankara Üniversitesi Fen Bilimleri Enstitüsü, Ankara 
Atlı, A., Koçak, N. ve Aktan, M. 1993. Ülkemiz çevre koşullarının kaliteli makarnalık buğday yetiştirmeye uygunluk yönünden değerlendirilmesi. Makarnalık Buğday ve Mamülleri Simpozyumu, 30 Kasım-3 Aralık, 345-351, Ankara

Atlı A., 1999. Buğday ve ürünleri kalitesi. Orta Anadolu'da Tahıl Tarımının Sorunları ve Çözüm Yolları Sempozyumu, 8-11 Haziran, Konya, s. 498-506

Atlı A., B. Aktan, T. Şanal, A. Kaplan Evlice, S. Ünsal, E. Dönmez, M. Köten, A. Pehlivan ve T. Özderen 2010. Makarnalık buğdayın kalite özellikleri ve kalite değerlendirme. Makarnalık Buğday ve Mamülleri Konferansı, 7-18 Mayıs 2010, Şanlıurfa, s. 91-109

Bayram, M. ve Öner, M.D. 2002. The new old wheat:convenience and nutrition driving demand for bulgur. World Grain, November, pp. $51-53$

Bilgin O., 2001. Bazı ekmeklik buğday (Triticum aestivum L.) çeşit ve hatlarında genetik uzaklıklar, verim ve kalite özelliklerinin belirlenmesi. Doktora Tezi Trakya Üniversitesi Ziraat Fakültesi (Basılmamış), Tekirdağ

Bilgin O., K.Z. Korkut, İ. Baser, O. Dağlioğlu, İ. Öztürk, T. Kahraman ve A. Balkan, 2010. Variation and heritability for semolina characteristics and grain yield and their relations in durum wheat (Triticum durum Desf.). World J. Agric. Sci., 6(3):301-308

Borelli GM, Troccoli A, Di Fonzo N. and Fares C., 1999. Durum wheat lipoxygenase activity and other quality parameters that affect pasta color, Cereal Chem., 76(3):335-340.

Borghil B., Corbellinii M., Minoia C., Palumbo M., Di Fonzo N. and Perenzin M., 1997. Effects of Mediterranean climate on wheat bread-making quality. European Journal of Agronomy, 6:145-154

Boyacıoğlu M. H. and D'appolonia B. L., 1994. Characterization and utilization of durum wheat for breadmaking.1. comparison of chemical, rheological, and baking properties between bread wheat flours and durum wheat flours Cereal Chemistry. 71(1):21-28

Boyacıoğlu M. H. ve Tülbek M.Ç., 2002. Makarnalık buğday kalitesine bir bakış. Tahıl 2002 Tahıl Ürünleri Teknolojisi Kongre ve Sergisi, s:1724 Gaziantep

Bozkurt M., 2012. Türkiye dünya durum buğdayı üretiminde üçüncü. Ekmek, Bisküvi ve Makarna Sektörü İhtisas Dergisi Yıl:1 Sayı:1 s:74-75 (Erişim tarihi:26.04.2017) https:// issuu.com/parantez/docs/bbm1
Braaten, M.O., Lebsock, K.L. and Sibbitt, L.D., 1962. Intergeneration relations of physical properties of dough and carotenoid pigment content in durum wheat. Crop Sci., 2: 277-281

Budak H., Karaltın S. ve Budak F., 1997. Bazı ekmeklik buğday çeşitlerinin (Triticum aestivum L. Em Thell) fiziksel ve kimyasal yöntemlerle kalite özelliklerinin belirlenmesi. Türkiye 2. Tarla Bitkileri Kongresi, 22-25 Eylül, Samsun, s. 534-536

Budak N., 2000. Heritability, correlation and genotype $\times$ year interactions of grain yield, test weight and protein content in durum wheats. Turkish Journal of Field Crops, 5(2): 35-40

Clarke F.R., J.M. Clarke, T.N. McCaig, R.E. Knox and DePauw R.M., 2006. Inheritance of yellow pigment concentration in seven durum wheat crosses. Can. J. Plant Sci., 86:133-141

Clarke J.M., Howes, N.K., McLeod, J.G. and DePauw, R.M., 1993. Selection for gluten strength in three durum wheat crosses. Crop Sci., 33: 956-958

Clarke, J.M., Clarke, F.R. and McCaig, T.N., 1998. Heritability of pigment content in three durum wheat crosses. In: Proceedings of the Ninth International Wheat Genetics Symposium, Vol. 2, Saskatoon, 1998, Slinkard, A.E. (ed.). University Extension Press, University of Saskatchewan, Saskatoon, pp. 182-184

Clarke, J. M., Clarke, F. R., Ames, N. P., McCaig, T. N. and Knox, R. E., 2000. Evaluation of predictors of quality for use in early generation selection. Durum wheat Improvement in the Mediterranean Region: New Challenges. C. Royo, MM Nachit, N. DiFonzo and JL Araus (Eds) International Centre for Advanced Mediterranean Agronomic Studies, Zaragoza, 439-446

Cubadda, R., Carcea M. and. Pasqui L.A., 1992. Suitability of the gluten index method for assessing gluten strength in durum wheat and semolina. Cereal Foods World 37: 866-869

Çağlayan M. ve Elgün A., 1999. Değişik çevre şartlarında yetiştirilen ekmeklik buğday hat ve çeşitlerinin bazı teknolojik özellikleri üzerinde araştırmalar. Orta Anadolu'da Tahıl Tarımının Sorunları ve Çözüm Yolları Sempozyumu, 8-11 Haziran, Konya, s. 513-518

Çiftçi C. ve Şenay A., 2005. Makarnalık buğdayda (Triticum durum desf.) Gama ışını ve EMS'in farklı dozlarının ayrı ayrı ve birlikte uygulanmasının $M_{2}$ bitkilerindeki etkileri Tarla Bitkileri Merkez Araştırma Enstitüsü Dergisi, 14 (1-2), 41-49. http://dergipark.gov. tr/tarbitderg/issue/11507/137045 
D’Egidio M., G., Mariani, B., M., Nardi, S., Novaro, P. and Cubadda, R., 1990, Chemical and techonological variables and their relationships: a predictive equation for pasta cooking quality, Cereal Chemistry 67, 275281

Dexter, J.E., R.R. Matsuo, K.R. Preston and Kilborn R.H., 1981. Comparison of gluten strength, mixing properties, baking quality and spaghetti quality of some Canadian durum and common wheats. Can. Inst. Food Sci. Technol., 14:108-111

Dick J.W. and Quick J.S., 1983. A modified screening test for rapid estimation of gluten strength in early-generation durum wheat breeding lines, Cereal Chemistry 60, 315-318

Elgün A. ve Türker S., 1999. Tahıl ürünleri teknolojisi. Selçuk Üniversitesi, Gıda Mühendisliği Bölümü, Ders Notları:4

Elgün A., Türker, S. ve Bilgiçli, N., 2001. Tahıl ve Ürünlerinde Analitik Kalite Kontrolü. Selçuk Üniversitesi Ziraat Fakültesi Gıda Mühendisliği Ders Notları. Konya Ticaret Borsası Yayın No: 2, Konya

El-Haramein, F.J., El-Saleh, A. and Nachit, M.M., 1996. Environtmental effect on durum wheat grain quality in Syria. $10^{\text {th }}$. International Cereal and Bread Congress, June 9-12 1996, Porto Carras, Greece

Elias E. M., 1995. Durum Wheat Products. Available from: http://ressources. ciheam.org/om/pdf/ a22/95605350.pdf, CIHEAM-IAMZ, 22, 2331.

Elias M., E. and Manthey F. A., 2005. End products: present and future uses: International Wheat Council, 63-85

Erkul E. 2006. Sulamalı koşullarda ileri ekmeklik buğday hatlarının tane verimi ve bazı kalite özelliklerinin belirlenmesi. ADÜ Ziraat Fakültesi Dergisi, 3(1):27-32

Fortini S., 1988. Some spesific aspects of durum wheat and pasta cooking quality evaluation in Europe. Durum Wheat Chemistry and Technology, American Association of Cereal Chemist Inc., St. Paul, M.N.

Kaplan Evlice A. ve Özkaya H., 2011. Makarnalık buğdayda farklı cihazlarla saptanan renk değerinin kalite yönünden değerlendirilmesi. Tarla Bitkileri Merkez Araştırma Enstitüsü Dergisi, 20(2):33-40

Kaplan Evlice A., 2016. Bulgurun fonksiyonel özellikleri ve teknolojik kalitesine buğday çeşidi ve üretim yönteminin etkisi. Doktora tezi Ankara Üniversitesi Fen Bilimleri Enstitüsü (Basılmamış) Ankara
Karaduman Y., Akın A., Türkölmez S. ve Tunca Z., 2015. Ekmeklik buğday ıslah programlarında gluten kalitesinin değerlendirilmesi için GlutoPik parametrelerinin kullanılabilirliğinin araştırılmasıTarla Bitkileri Merkez Araştırma Enstitüsü Dergisi, 24 (1), 6574. http://dergipark.gov.tr/tarbitderg/ issue/11532/137342

Koyuncu M., 2009. Yerel durum buğday çeşitlerinin makarnalık kalitelerini etkileyen önemli parametreler bakımından taranması (Yüksek Lisans Tezi). Gaziosmanpaşa Üniversitesi Fen Bilimleri Enstitüsü Gıda Mühendisliği Anabilim Dalı, Tokat

Köksel, H., Sivri, D., Özboy, Ö., Başman, A. ve Karacan H. D., 2000. Tahıl Laboratuarı El Kitabı, Hacettepe Üniversitesi Mühendislik Fakültesi Yayınları, Yayın no: 47, s. 106

Kün E. 1988. Serin İklim Tahılları. Ankara Üniversitesi Ziraat Fakültesi Yayınları. No:1032 Ders Kitabı, 299, s. 322, Ankara

Landi A., 1995. Durum wheat, semolina and pasta quality characteristics for an Italian food company. In: Durum wheat quality in the Mediterranean Region, ed. di Fonzo, N., Kaan, F. and Nachit, M. Série A: Séminaires Méditerranéennes, No. 22. Options Méditerranéennes, Zaragoza, España: Instituto Agronomico Mediterraneo de Zaragoza, pp. 33-42

Levy A.A. and Feldman M., 1989. Location of genes for high grain protein percentage and other quantitative traits in wild wheat Triticum turgidum var. dicoccoides. Euphytica, 41: 113-122

Liu C.Y., K.W. Shepherd and. Rathjen A.J., 1996. Improvement of durum wheat pastamaking and breadmaking qualities. Cereal Chemistry, 73:155-166

Manthey F., 2001. Durum Wheat Color. www. ag.ndsu.nodak.edu/plantsci/breeding/durum

Mariani B.M., D’Egidio, M.G. and Novaro P., 1995. Durum wheat quality evaluation: Influence of genotype and environment, Cereal Chemistry 72(2):194-197

Melik M., 2014. Bazı yerel ve tescilli makarnalık buğday çeşitlerinin verim unsurları, bulgur kalitesi ve randımanının incelenmesi. Yüksek Lisans Tezi, Mustafa Kemal Üniversitesi, Fen Bilimleri Enstitüsü, Tarla Bitkileri Anabilim Dalı, 97, Hatay

Miadenow N., Przulj N., Hristov N., Djuric V. and Milovanovic M., 2001. Cultivar-byenvironment interactions for wheat quality traits in semiarid conditions. Cereal Chem., 78:363-367 
Mohammed A., B. Geremew and Amsalu A., 2012. Variation and associations of quality parameters in Ethiopian durum wheat (Triticum turgidum L. var. durum) genotypes. International Journal of Plant Breeding and Genetics, 6(1):17-31

Ozan A. N., 2004. Ekmeklik buğdayda kalite ıslahı ve kalite kriterleri. (Yayınlanmadı) Ankara.

Özboy Ö., 1998. Bulgur üretiminde verim ve kalite belirlemede kullanılabilecek testler ile üretimin nişasta ve protein özellikleri üzerine etkileri. Doktora Tezi, Hacettepe Üniversitesi Fen Bilimleri Enstitüsü, Ankara, s. 123

Özkaya B. ve Özkaya H., 1993a. Buğday, irmik ve makarna kalitesini değerlendirme yöntemleri. Makarnalık Buğday ve Mamulleri Simpozyumu, 30 Kasım- 3 Aralık 1993, 296306, Ankara

Özkaya H ve Özkaya B., 1993b. Makarna kalitesinde buğday bileşiminin önemi. Makarnalık Buğday ve Mamulleri Sempozyumu, s:189195, Ankara

Özkaya H ve Özkaya B., 2005. Öğütme Teknololojisi Gıda Teknolojisi Derneği Yayınları No: 30 s. 268-283 Ankara

Özderen Ünsal N.T., 2009. Süne (Eurygaster spp.) zararının makarnalık buğday ve makarna kalitesi üzerine etkileri. Doktora Tezi, Hacettepe Üniversitesi, Fen Bilimleri Enstitüsü, Gıda Mühendisliği Anabilim Dalı, 74, Ankara

Pehlivan A., A. Kaplan Evlice, T. Şanal, N. Çinkaya, T. Özderen ve Keçeli A., 2008. Makarnalık buğdaylarda ( Triticum durum Desf) irmik rengi ile tane rengi arasındaki ilişkinin incelemesi. Ülkesel Tahıl Sempozyumu, 2-5 Haziran 2008, s. 819-823, Konya

Pehlivan A. ve Ünver İkincikarakaya S., 2016. The comparison of flour milling methods for determination of quality in early stages of durum wheat breeding program $15^{\text {th }}$ International Cereal and Bread Congress April 18-21 İstanbul, Türkiye, pp 301

Pomeranz Y., 1998. Wheat:Chemistry and Technology AACC, St. Paul, Minnesota,USA

Sarrafi A., Ecochard, R. and Grignac, P., 1989. Genetic variability for some grain quality characters in tetraploid wheats. Plant Var. Seeds, 2: 163-169

Salantur A., Yazar S., Dönmez E. ve Akar T., 2011. Kışıı ekmeklik buğday $F_{2}$ popülasyonlarının anter kültüründe bitki rejenarasyonuna tepkisinin belirlenmesi Tarla Bitkileri Merkez Araştırma Enstitüsü Dergisi, 20 (1): 15-21 http://dergipark.gov.tr/tarbitderg/ issue/11501/136998
Salantur A., 2013. Sözlü görüşme Tarla Bitkileri Merkez Araştırma Enstitüsü Buğday Islah Bölümü Ankara

Sakin M.A., Sayaslan A., Duzdemir O. and Yuksel, F., 2011. Quality characteristics of registered cultivars and advanced lines of durum wheats grown in different ecological regions of Turkey. Can. J. Plant Sci., 91, 261-271

Sayaslan A., 2007. Tahılların kimyasal bileşimi ve kalite, Ders notları

Sissons M. J. and Hare R. A., 2002. Tetraploid wheatA resource for genetic improvement of durum wheat quality. Cereal Chem., 79 (1), 78-84

Şahin M., Göçmen Akçacık A., Aydoğan S., Hamzaoğlu S. ve Türköz M., 2015 Assessment of quality of durum wheat breeding material by means of mixograph parameters Bahri Dağdaş Bitkisel Araştırma Dergisi, 3: 1-6 http://dergipark.gov.tr/bdbad/ issue/25864/272657

Şahin M., Aydoğan S., Akçacık A. ve Taner S. 2009 Orta Anadolu için geliştirilmiş bazı ekmeklik buğday genotiplerinin alveograf analizi yönünden değerlendirilmesi Bahri Dağdaş Uluslararası Tarımsal Araştırma Enstitüsü Müdürlüğü Bitkisel Araştırmalar Dergisi.2: 1-9 Konya

Şehirali S. ve Özgen M., 1988. Bitki ıslahı, A.Ü. Ziraat Fakültesi Yayınları: 1059, Ders Kitabı: 310, A.Ü. Basımevi, Ankara, s. 261

Troccoli A., Borrelli, G.M., De-Vita, P., Fares, C. and Di-Fonzo N., 2000, Durum wheat quality: a multidisciplinary concept, Journal of Cereal Science 32: 99-113

Tsegaye D., Dessalegn T., Dessalegn Y. and Share G., 2012. Genetic variability, correlation and path analysis in durum wheat germplasm (Triticum durum Desf) Agricultural Research and Reviews Wudpecker Research JournalsVol. 1(4), pp. 107 - 112 http://www. wudpeckerresearchjournals.org/ARR

Ünver İkincikarakaya S., 2016. Serin iklim tahılları genetik ve sitogenik Ankara Üniversitesi Fen Bilimleri Enstitüsü Yüksek Lisans Ders Notları (Basılmamış) Ankara

Wasık R. J., 1978. Relationship of protein composition of durum wheat with pasta quality and the effects of processing and cooking on these proteins, Can. Inst. Food Science Technology 11: 129-134

Williams P., El-Haramein, F. J., Nakkoul, H. and Rihavi, S., 1988. Crop Quality Evaluation Methods and Guidelines, International Center for Agricultural Research in the Dry Areas. ICARDA, Aleppo, Syria, pp. 145 
Yan W., Hunt L. A., Sheng Q. and Szlavnics, Z., 2000. Cultivar evaluation and mega-environment investigation based on the GGE biplot. Crop Science, 40(3): 597-605

Yazar S. ve Karadoğan T., 2008. Bazı makarnalık buğday genotiplerinin orta anadolu bölgesinin taban ve kıraç arazi koşullarında verim ve kalite özelliklerinin belirlenmesi Süleyman Demirel Üniversitesi Ziraat Fakültesi Dergisi $3(2): 32-41$

Yazar S., Salantur A., Özdemir B., Alyamaç M. E., Kaplan Evlice, A Pehlivan A., Akan $K$ ve Aydoğan S., 2013. Orta Anadolu bölgesi ekmeklik buğday ıslah çalışmalarında bazı tarımsal karakterlerin araştırılması Tarla Bitkileri Merkez Araştırma Enstitüsü Dergisi, 22 (1): $32-40$
Yüksel F., 2009. Bazı Makarnalık Buğday İleri Islah Hatlarının Kalite Özellikleri ve Stabilite Yetenekleri (Yüksek Lisans Tezi). Gaziosmanpaşa Üniversitesi Fen Bilimleri Enstitüsü Gıda Mühendisliği Anabilim Dalı, Tokat 